\title{
レーダ雨量計情報の動画像解析による降雨予測手法の 提案と流域平均降雨量の推定法に関する研究
}

\author{
山田 正 ${ }^{1} \cdot$ 日比野忠史 ${ }^{2} \cdot$ 中津川 誠 ${ }^{3}$ 藤沢 充哲 ${ }^{4} \cdot$ 森永 博史 \\ 1 正会員 工博 中央大学教授 理工学部土木工学科（テ112 東京都文京区春日 1-13-27） \\ 2 正会員 L博 広島大学助手工学部地域環境工学科 \\ 3 正会員 工博 北海道開発局開発土木研究所 \\ 学生員 中央大学大学院 理工学研究科
}

\begin{abstract}
レーダ雨量情報の動画像を用いた降雨の短時間予測手法の提案とティーセン法による流域平均降雨量の推定精 度を検証した。次にレーダ雨量情報を動画像化し, これを用いて人間の月視による降雨の短時開争測を行った。 この結果リードタイムが 1 時間の時の予測値はレーダ雨量計による観測值と良好な一致を示していた。リード夕 イムが 2,3 時間と長くなるにつれて予測精度は低下するが, 従来の予測手法と比較しても工学上充分な実用性 を有していることを確認した。レーダ雨量情報を用いて, ティーセン法の精度を検証した。この結果, 本研究で 対象とした流域においては, 実雨量との相対推定誤差は雨量計 1 台あたりの支配而積のほぼ 0.6 乗で減少してい ることがわかった.
\end{abstract}

Key Words : radar raingauge, animation, short-term rainfall prediction, Thiessen method, average-rainfall-depth over watershed

\section{1.はじめに}

本研究は, レーダ雨量情報の動画像を用いた人間の目 視による降雨の短時間予測手法の提案亡, 流域平均降雨 量を推定する手法の一つであるティーセン法の精度を検 証したものである.

降雨状況を面的に捕らえることができるレーダ雨量計 の降雨情報を動画像化する事で誰もが容易に降雨域の移 動, 成長, 減衰の様子を把握することができるようにな る.本研究で提案する降雨予測手法は動画を用いており, 複雑な数値計算や専門的知識を必要としないという利点 を有する.レーダ雨量情報を用いた短時間降雨予測手法 は現在まで数多く提案されており，1)運動学的手法，2) 統計学的手法, 3)力学的手法に分類できる. 運動学的手 法の代表的な手法として, 立平による $700 \mathrm{mb}$ の観測風 でレーダエコーを移流させる方法" ${ }^{1}$, 浅井らによる 2 枚 のレーダエコー図から相互相関関数を求めて雨域べクト ルを得る方法 (相互相関関数法 $)^{2 \dagger}$, 大倉らによるレ一 ダエコー図をあるいき值を境に 2 值化して関連係数を求 めそれから移動ベクトルを得る方法 $(\text { 雨域追跡法 })^{31 \sim 5)}$, 椎葉らによる移流モデルを雨域移動ベクトルに適用した 方法 ${ }^{6}$, 運動学的手法と力学的手法両方の側面を加味し た著者ら（山田・中津川ら）による降雨の物理モデルを 考慮した降雨モデル7), なビがあげられる.レーダ雨量
情報の動画化においては, 地上雨量計により観測された 降雨データと雨量計による観測值とを比較し,レーダ雨 量計が受信したレーダ反射因子を降雨強度に変換する際 のレーダ定数を一雨毎に同定し直す事でレーダ雨量計の 精度を向上させた。レーダ雨量情報の動画のみを用いた 降雨の短時間予測においては動画像による降雨域の移 動, 成長, 減衰のパターン化, 移動経路, 移動速度亡雨 域の大きさについての解析を行い, これらの解析結果を 用いて降雨予測を行った. 従来より流域平均降雨量の推 定にはティーセン法が主に用いられており, 橋本ら”に より地上での精密観測から雨量計 1 台あたりの支配面積 と相対推定誤差の関係が明らかにされている.ここでは 降雨状況を面的に捕らえることができるレーダ雨量計 データを用いてティーセン法で使用する地上雨量計の台 数による精度の違いを検証し, 地上雨量計による観測所 の必要数について考察を行った.

\section{2. レーダ雨量計の観測緒元と解析に用いたデー タ}

\section{（1）レーダ雨量計の解像度と観測範囲}

本研究で用いたレーダ雨量計は北海道開発局が札幌市 の北東約 $50 \mathrm{~km}$ にあるピンネシリ山の山頂(標高 1100 $\mathrm{m}$, 北緯 $43^{\circ} 29^{\prime} 20.7^{\prime \prime}$, 東経 $\left.141^{\circ} 42^{\prime} 35.3^{\prime \prime}\right)$ に設置した道 


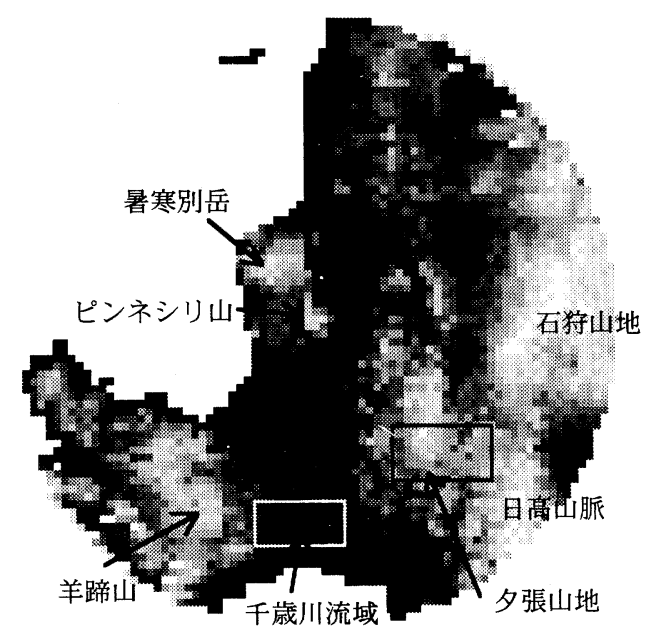

図-1 レーダ雨量計の観測範囲（半径 $120 \mathrm{~km}$ ) と地形 (この図は地形図をデジタルマップにしたものである.レーダは 半径 $120 \mathrm{~km}$ の範囲で定量的に観測している. 図はレーダの観 測メッシュに地形の標高データを入れて表示している。色の白 い点ほよ゙標高が高いことを示している．図中の口で囲んだ地域 は図2に示す地上雨量計を設置した位置を示す。

央レーダである，道央レーダはレーダサイトを中心に半 径 $198 \mathrm{~km}$ の範囲を観測しているが，定量的な情報は半 径 $120 \mathrm{~km}$ の範囲で得ることができる．ビーム幅は鉛直 水平方向 $1.2^{\circ}$, 定量範囲内では方位方向に $2.8125^{\circ}\left(360^{\circ}\right.$ を 128 等分)，動径方向に $3 \mathrm{~km}$ の空間解像度をもって おり，観測時間間隔は 5 分である。レーダは 5 分間に 25 回転しており，その平均値をとって 5 分間の平均降 雨強度としている．図一1には道央レーダが観測を行っ ているピンネシリ山を中心とした半径 $120 \mathrm{~km}$ のレーダ 観測範囲の地形図（標高データはレーダデータと同様の メッシュでサンプリングしている) が示されている。こ の範囲内には図に示すように $2000 \mathrm{~m}$ 級の山々が連なる 石狩山地, その南西には日高山脈 (1800 m 級), 夕張山 地（1500 m 級）がある。またピンネシリ山北西に暑寒 別岳 $(1100 \mathrm{~m})$, 南西に羊蹄山 $(1890 \mathrm{~m})$ がある.

\section{（2）解析に用いたデータ}

解析に用いたデー夕は上述の道央レーダによるレーダ 雨量データ(レーダ反射因子) と地上雨量データである. 地上雨量データは図一1 中に口で囲んだ千歳川流域及び 夕張岳斜面に著者らが設置した転倒マス型雨量計 $(0.5$ $\mathrm{mm}$ マス）合計 21 基によって観測されている. 観測期 間は 1988 年から 1994 年までの 7 年間の 7 〜 10 月であ り，この間に観測した降雨は著者らにより観測された任 意の地点の一雨の総降雨量が $10 \mathrm{~mm} / \mathrm{h}$ 以上の約 50 種類 である。

\section{a）レーダ反射因子から降雨強度への変換}

降雨強度 $R(\mathrm{~mm} / \mathrm{h})$ はレーダ反射因子 $Z$ からレーダ

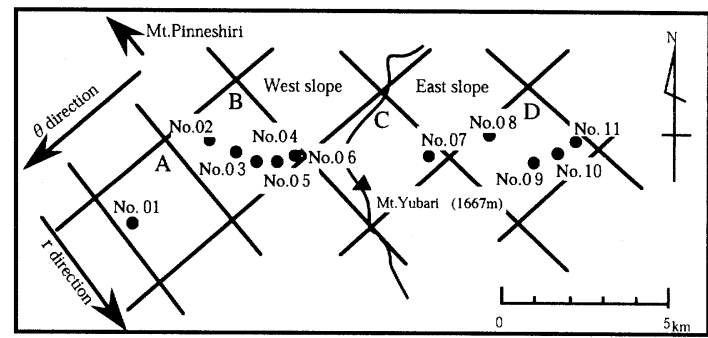

(a) 夕張山地

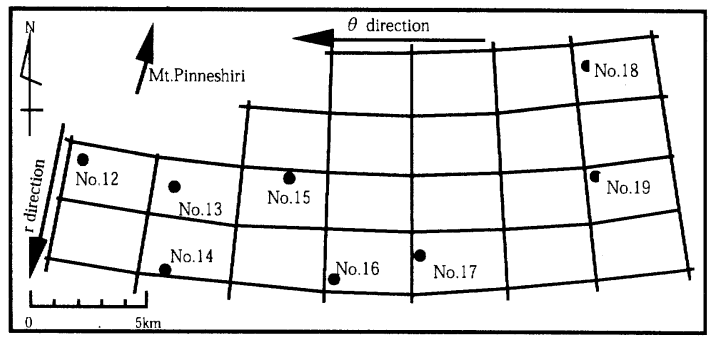

(b) 千歳川流域

図一2レーダの観測メッシュと地上雨量計の設置位置

で示したのが雨量計の設置位置， A D D は雨量計の設置した 地点に対忘するレーダメッシュを表わしている，A，Bは夕張 岳の西側， C，D は東側在観測している。各メッシュの平均標 高はA は約 $450 \mathrm{~m}, \mathrm{~B}$ は約 $700 \mathrm{~m}, \mathrm{C}$ は約 $1400 \mathrm{~m}, \mathrm{D}$ は約 700 $\mathrm{m}$ である。地上雨量計は $\mathrm{A}$ に 1 基， $\mathrm{B}$ に 5 基， $\mathrm{C}$ に 1 基， $\mathrm{D}$ に 4 基設置されている.)

定数 $B, \beta$ を用いて次式によって求められる.

$$
Z=B R^{\beta}
$$

$Z\left(\mathrm{~mm}^{6} / \mathrm{m}^{3}\right)$ は降雨による電波の散乱面積でレーダに よって受信される観測值である. $B$ 亡 $\beta$ は雨滴粒径分 布と雨滴の落下速度から算定される值であるが，実際に は地上で観測した雨量強度からキャリブレーションして 求めら机ている：道央レーダで用いられている $B$ と $\beta$ の值は以下の通りである.

$$
\begin{aligned}
& R<8 \mathrm{~mm} / \mathrm{h} \text { の時 } \cdots \cdots B=180, \beta=1.6 \\
& R \geqq 8 \mathrm{~mm} / \mathrm{h} \text { の時 } \cdots \cdots \cdot B=410, \beta=1.2
\end{aligned}
$$

b) レーダ雨量の観測メッシュと地上雨量の観測位置

レーダ雨量計は一雨の観測において膨大なデー夕を扱 うため，デー夕管理等の運用上の問題加ら解像度に制限 を受けており，実際に運用されている観測メッシュの大 きさは $3 \mathrm{~km} \times 3 \mathrm{~km}$ 程度の解像度となっている。このた め，1つの観測メッシュ内に地形の起伏が存在し，観測 值に地形の影響が含まれていることが予想される。した がって，本研究では観測メッシュ内が平野で占められる 千歳川流域（メッシュ内の標高差 $25 \mathrm{~m}$ 未満）と夕張岳 斜面（メッシュ内の標高差約 $800 \mathrm{~m}$ ）で観測された地上 雨量デー夕を用いている，図一2には千歳川流域及び夕 張岳斜面に設置した地上雨量計の位置とレーダ雨量計の 観測メッシュの関係が示されている。千歳川流域では約 $20 \mathrm{~km}$ で $100 \mathrm{~m}$ の標高差内に 5 基の雨量計が設置されて 


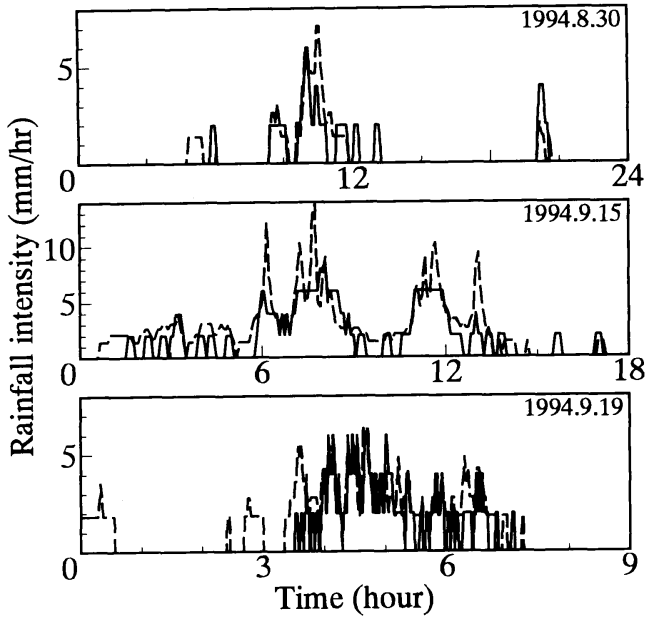

図一3 転倒杵型雨量計で観測した地上雨量強度 (千歳川流域) と冬降雨ごとにレーダ定数を変えて算出したレーダ雨量 強度の経時变化の比較（5 分閒強度）

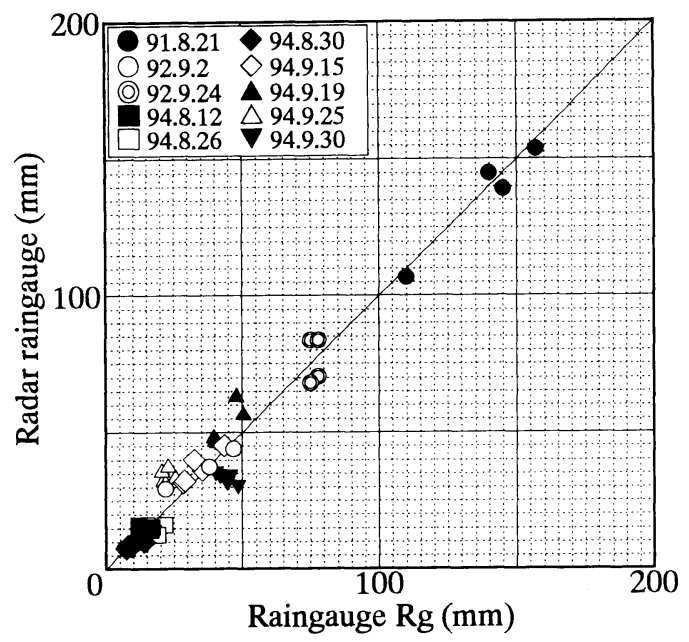

図一 4 レーダ雨量と地上雨量の比較 (千筬川流域) (レーダ雨 量は一雨ごとに $B, \beta$ を同定して求めている。一雨に対 しては 5 地占で同一の㑬を使用している。）

\section{（2）レーダ定数の特性}

図一-3はレーダ雨量と地上雨量を比較したものであ る.ここで用いた地上雨量データ ( 5 分每の降雨強度) は，図一2（b）に示した干歳川流域に設置された地上 雨量計データである。実線は地上雨量, 点線は上記の方 法で求めた時問降雨強度を表している.この結果からも i）一雨每にレーダ定数を同定し直す事でレーダ雨量強 度は地上雨量強度を再現することができる。ii）一雨中， 極端に降雨強度の精度は変化しないことがわかる。図一 4 は干歳川流域の 5 地点でレーダ雨量計と地上雨量計に よって観測された一雨降雨量を比較したものである。困 中において 5 地点で観測された雨量は同記号で表されて いる. $20 \mathrm{~km}$ 以上離れた地点で同一のレーダ走数を用い て雨量を精度良く表されることから空問的な広がりに対 しても本研究で扱った千歳川流域の範囲（図一1参照） 内では一雨に対して同一のレーダ定数を用いることがで きる．図一 5 は雨滴計観測（中央大学キャンパス内）に よって求められたレーダ定数 $(\triangle, \bigcirc, \square) の$ 分布を表し たものである ${ }^{101}$.この図からレーダ定数の値は…雨ごと に異なるが，ランダムな值をとるのではなく，降雨の成 因別に分類できることがわかる.

\section{（３）地形によるレーダ定数の変化}

図一6（a）中の実線で囲んだ雨は前線による降雨で あるが，これらは雨域が数 $100 \mathrm{~km}$ のケケール(レーダ 観測範囲全体を覆うスケール；後述の図一9参照）に及 ぶ降雨である。図の左下の方向に行くほ上゙降雨域は広範 井になる傾向がある。図一6（b）には図一6（a）上同 様の方法で夕張岳西側斜面 $940 \mathrm{~m}$ の地点の降雨量から 


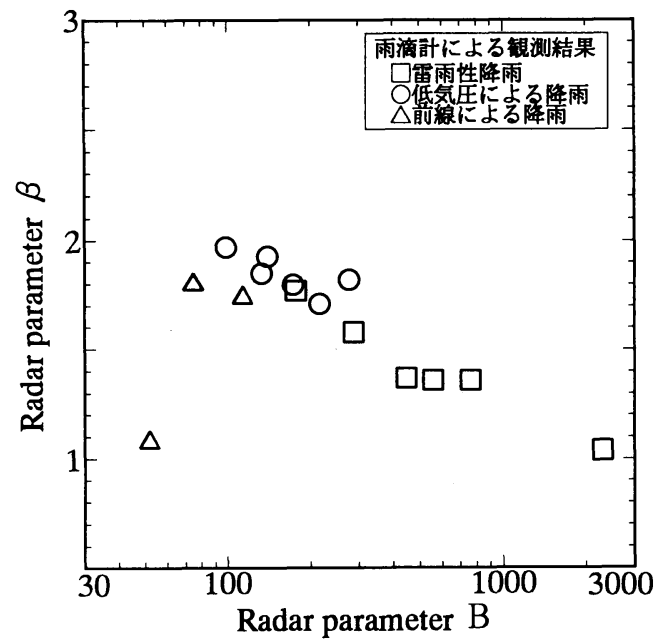

図一5 降雨の成因別に表したレーダ定数 $B, \beta$ の分布、 (中央大学構内に設置した雨滴計で観測した雨滴粒径分布から求 めた $B, \beta$ の分布を表している.)

求められたレーダ定数の分布が表わされている. この図

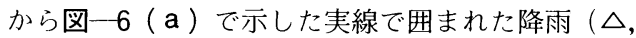

○, ○, ○)は, 夕張岳ではレーダ定数の值が右側に（図 一6（b）では破線の範囲から実線の範囲へ）シフトし ているのがわかる．このことは図—5の雨滴観測による レーダ定数の傾向を考慮すると, 夕張岳が山地流域であ り地形によって上昇風が引き起こされ雨滴が成長し夕張 岳付近では雷雨的な降雨に変化していることが予想さ れ，降雨の種類と地形に合ったレーダ定数を用いること が必要があることを示している.また,雨域の水平スケー

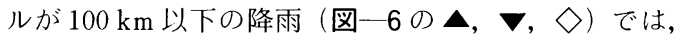
レーダ定数の変化が小さく, その值は変化していない. なお，降雨では千歳川流域と夕張岳で $B, \beta$ の值が 異なっているが, この雨は雷雨であり, 夕張岳で雨が集 中的に降っているためである. 雨域の水平スケールが小 さい雨（例えば雷雨や寒冷前線による雨）は上昇流が強 く，地形の影響が小さために雨滴粒径分布は山地流域 でも変化が小さいと考えられる.

\section{4. レーダ動画像から得られる情報の総観的解析}

図一7は 3 つの異なる降雨のレーダ画像を 10〜15 分 間隔で示したものである.（a）には1993.9.30の 07:30 〜 08:55の 1.5 時間，（b）には1990.9.3の 19:00 〜 19:50の 1 時間，（c）.には1993.9.30の 19:30〜 20:20 の 1 時間の雨域の移動の様子が示されている. 図一 8 之 図一9の（a）には累積降雨量分布，（b）には降雨域 の時間変化が示されている.（b）に示した個々の降雨 域は最後に累積された時間の降雨域の瞬間値が示されて

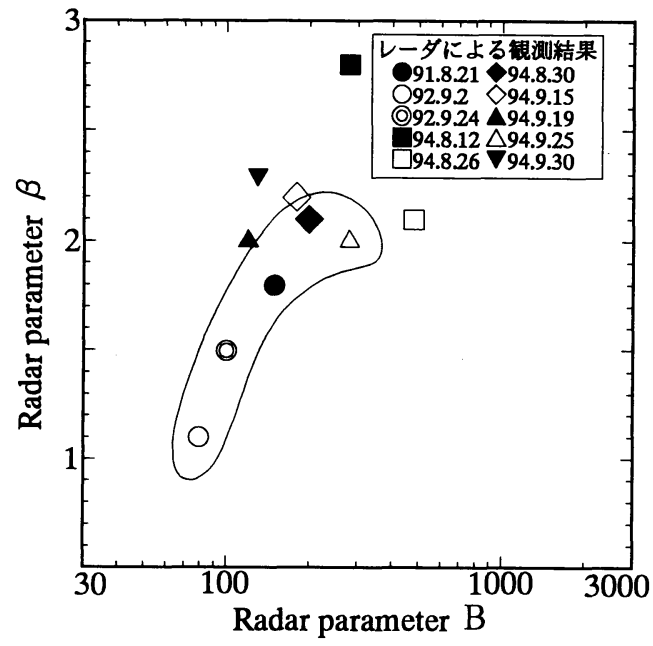

図一6（a）千歳川流域におけるレーダ定数 $B, \beta$ の分布 (千歳川流域で観測されたレーダ雨量と地上雨量から求めた $B$, $\beta$, 実線で囲んだ $(B, \beta)$ は北海道全域に降雨があった場合であ る.)

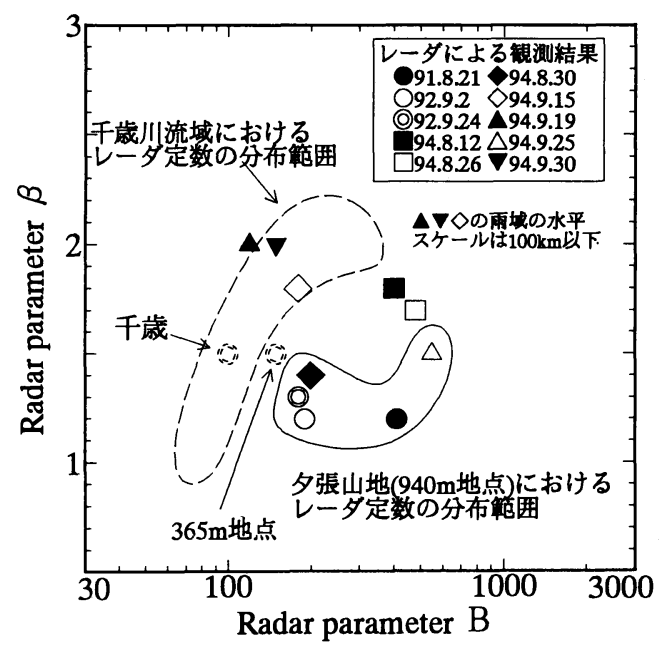

図一（b） 夕張岳におけるレーダ定数 $B, \beta$ の分布 (夕張岳斜面の標高 $940 \mathrm{~m}$ で観測された地上雨量強度から換算し ている. ○及び実線で囲んだ雨は平地から山地に向って $B, \beta$ が変化していく様子を示している. )

いる. 図一8には1994. 8.26.21:00〜27.08:55 の 12 時間, 図一9には1992.9.24.20:00〜25. 19:55の 24 時間の降雨 が示されている.

\section{（1）地形の影響を強く受けた降雨域の移動及び成長}

図一7（a）の降雨では広い範囲で雨が降っており, 雨域が南から北に向って移動している. 雨域の移動に伴 い, 暑寒別岳及び夕張山地で雨域が成長しているのがわ かる. 暑寒別岳で雨域が成長し，その後北方向に移流し ている，夕張山地では山地に沿って雨域が成長し，あた 

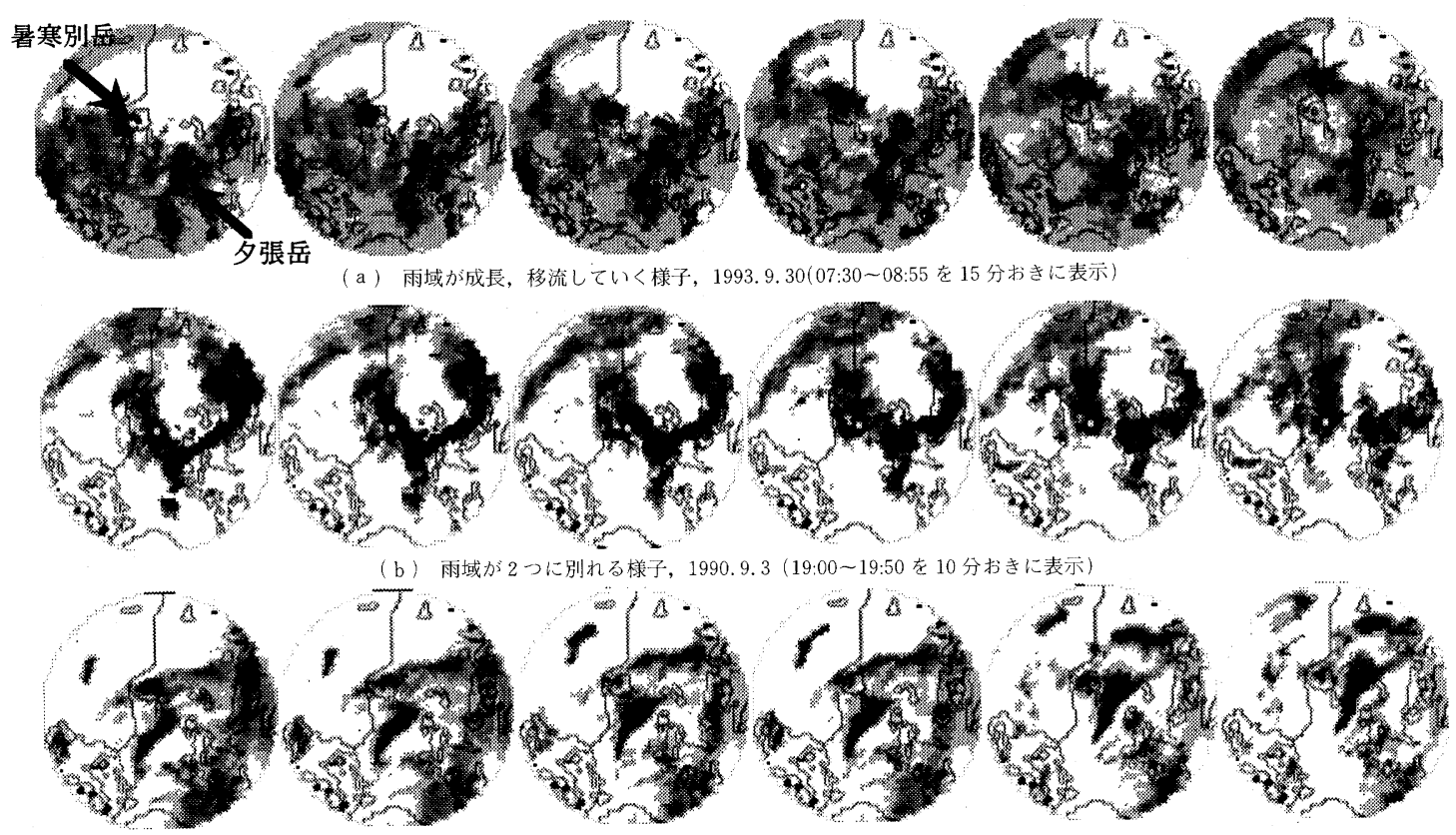

(c) 平地から降雨域が発生する様子, 1993.9.30(19:30 20:20)

図-7レーダ画像（いずれも時間軸は右向きが正，色が黒いところほぼ降雨強度が強い．白黒画像）

かも雨域が停滞して雨域の移流がないようにみえてい

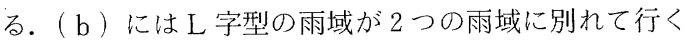
様子が示されている. 雨域は拡散することなく移動して いるが，ピンネシリ山付近で雨域が停滞し，雨域が分断 されている. 分断された雨域は夕張岳北側の窪地沿い進 んで行くが, 石狩山地で再び停滞し山地地形を越えるこ とができていない様子がわかる。

\section{（2）降雨域の発生}

図一7（c）は地形に起伏のない石狩平野の中央から 雨域が発生する様子を示している。ここで示した雨域の 発生原因は地形の影響を受けている場合の雨域の成長上 異なり大気の鉛直不安定あるいは大気によって作られた 壁（三二前線）が原因となっていると考えられる．石狩 平野中央部付近からの雨域の発生は，他の降雨でも多く 観測されており，海よ山地で囲まれたこのような地域は 雨雲が発生し易い地形であると言える.

\section{（3）降雨の集中特性}

図一 8 に示した降雨では $2 つ の$ 雨域が西から東へ向 かって移流している. 前半 (0:55-4:55) は20〜60 k m スケールの雨域が群として移流し, その後, $200 \mathrm{~km}$ を 越えるスケ一ルの雨域が移流している.この2つの雨域 はそのスケールが数倍異なっており, 全体の降雨量は後 半の雨域の通過によって決まっているが, 両雨域とも直 線的に移流しており, 移動速度の変化もほとんどない。
図一9の降雨の雨域は広く, 約 2 日間にわたって夕張 岳で $200 \mathrm{~mm}$ を越える降雨量をもたらしている. 降雨当 初には20〜80 km スケールの 10 数個の雨域が成長しつ つ, 西から東へ移流し, その後レーダ観測範囲全体を覆 うスケールの雨域が 20 時間以上かけて道央を横断して いる，累積降雨量の動画から広い範囲で降雨量が多く なっており, 特に, 山地流域では降雨強度が強くなり, 降雨量が増大していくのがわかる.

以上のように雨域の移動を瞬間，瞬間でみると一雨の 中にもいろいろなパターンで降雨域が成長し移流してい く様子がわかるが, 総降雨量でみると降雨量が集中して いく地域がわかる (図一と 8 ).このことから，一降雨 中に移流していく雨域の各々の特性は局域的な大気条件 下で逐次変化していくのではなく，メソスケールの大気 の条件下で各々の雨域の特性を大きく変化させることな く移流していくと考えられる。

\section{（4）降雨域の移動特性}

a) 地形による降雨域の成長及び移動のパターン

降雨域の移動・成長には地形が強く影響している. 地 形による雨域の移動・成長パターンを表一 1 に示した. 雨域の移動・成長は大きく分けるとi）地形によって雨 域が拡大された後, 移流していく場合, ii) 雨域の成長 はないが移流が妨げられ山の風上側に雨域が溜る場合, iii）地形によって雨域がトラップされ（移流を妨げられ） 雨域が成長する場合の3つのパターンに分けることがで 


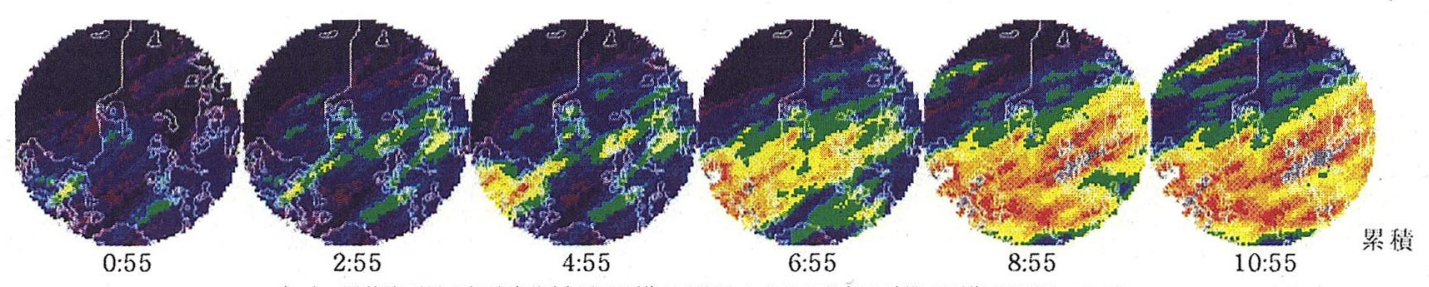

(a) 累積降雨量の経時変化(左端の画像は 23:00 からの 5 分每 2 時問の画像を累積している。

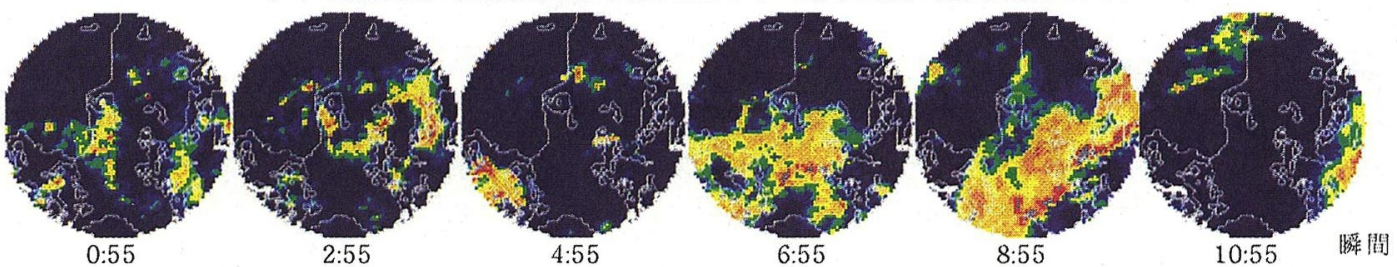

(b) 䍗積された最後の時問に刘応する䀟問の雨域の様子

図一8 1994.8.26 23:00 27 08:55 のレーダ画像（2 時間毎;下段の数字は時刻を表わしている.

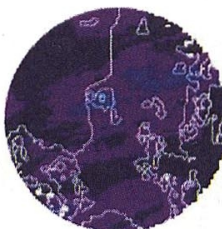

$21: 55$

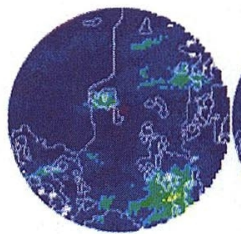

9:55

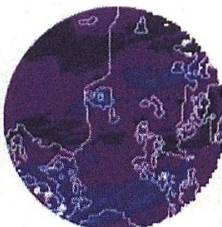

$23: 55$
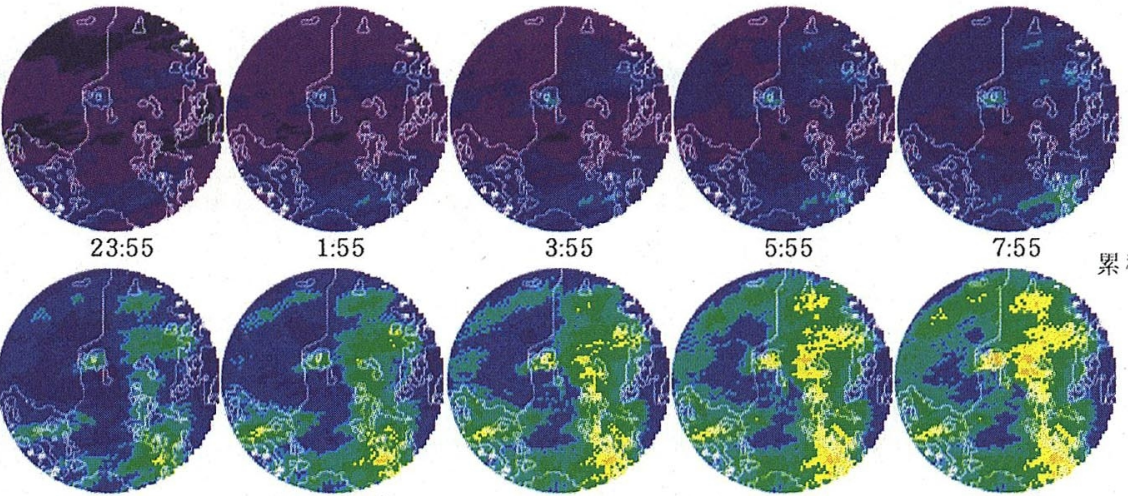

$11: 55$

$13: 55$
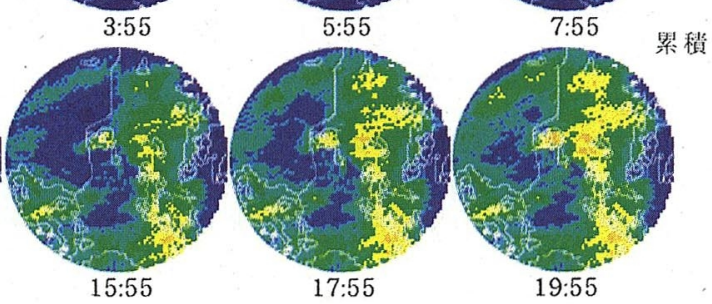

(a) 累樍降雨量の経時変化 (上段左端の画像は 09:00 からの 5 分毎 12 時問の画像を累積している.)
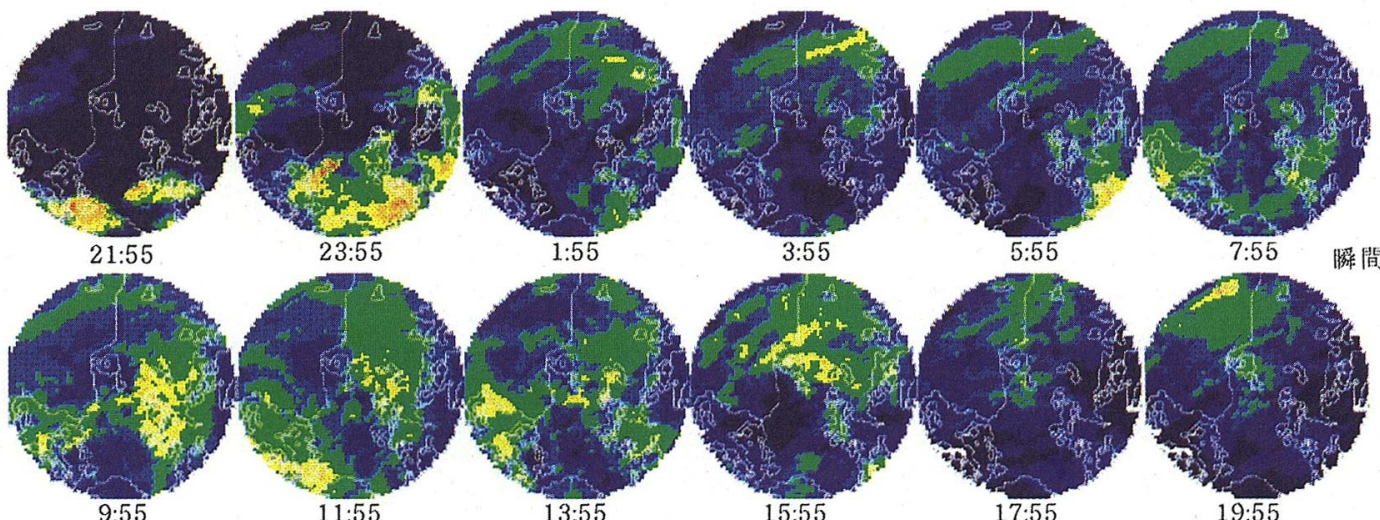

(b) 累積降雨の経時変化とその最後の時刻に対応する降雨の状沉

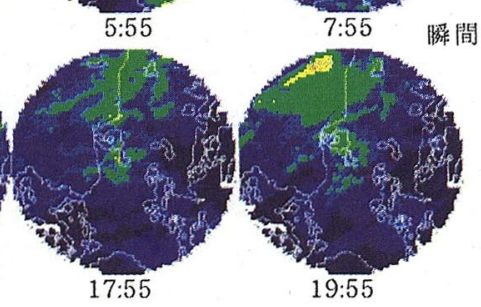

図一9 1992.9.24 20:00 25 19:55 のレーダ画像（2 時間毎;下段の数字は時刻を表わしている.
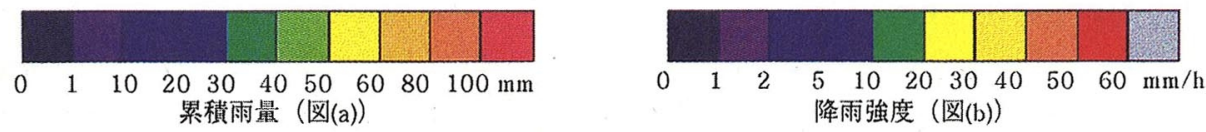
表一1 地形の影響による雨域の移動・成長パターン

(山は川頂，実線で囲まれた部分は降雨域を表している)

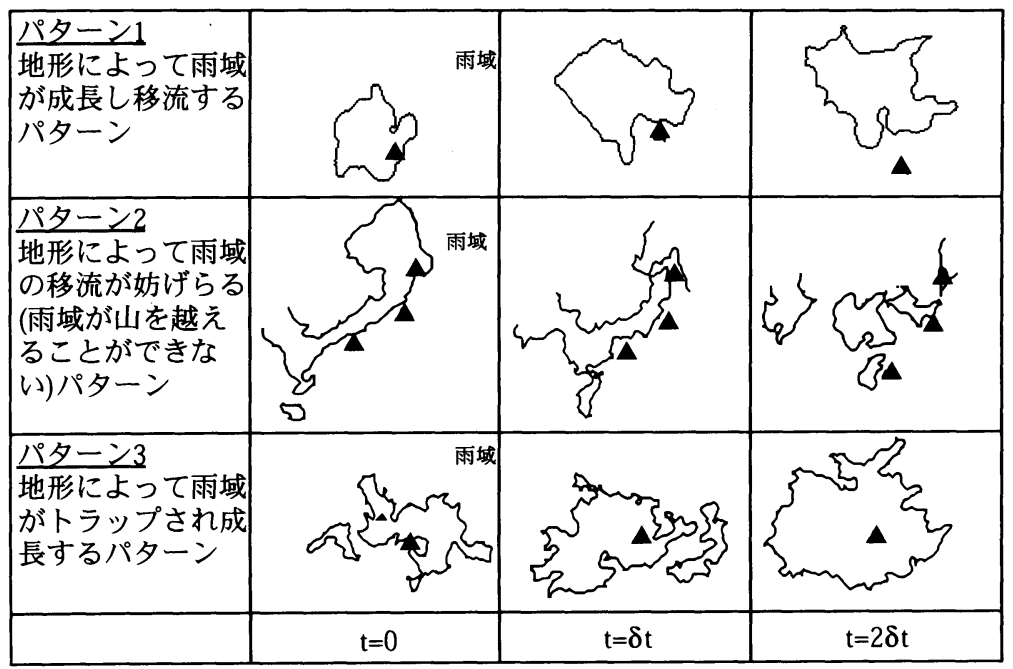

きる. 表-1のムは山頂, 実線で囲まれた部分は降雨域 を表している。

最も出現頻度の高いのはパターン1 (図一7（a ）に示 した暑寒別岳付近）であり，山地流域で降雨量が増加し ていく様子がよく観察される. 著者らによる山地流域で の降雨観測の結果 ${ }^{11}$, 「山地流域では降雨量は標高が高 い地点ほよ゙多い傾向があり, 降雨量分布は地形形状を風 下側に数 $\mathrm{km}$ 平行移動した形状と一致する」ことが見出 されているが, パターン 1 の雨域の移動・成長が起こる ことによって上記の降雨量の分布形状が決定されている と考えられる.

パターン $2($ 図一7 (b )) は雨雲の位置が低い場合に 観測され，この場合には風上側で雨量が増加する. 出現 頻度はパターン 1 に比較して少ないが,このパターンの 降雨ではレーダ雨量計は降雨量を過小に評価する傾向 (雨量をとらえられない場合もある)にある。したがっ て,このパターンが観測される場合には地上雨量との比 較を行う等の対策が必要である. パターン 3 (図一7 ( a ) の夕張山地付近) はパターン 1 よりもさらに地形の影響 か強くでる現象である。このパターンでは山地流域付近 の雨域は平地の雨域と同様の速度で移流が起こっている にもかかわらす，連続的な水蒸気の補給によってあたか も雨域が停滞しているように観測される.

\section{b）降雨域の移動経路}

動画像から一降雨の中には水平スケールのことなる雨 域が数個〜10 数個存在していること, 観測範囲の 200 $\mathrm{km}$ のスケール内では雨域の移動方向は変化せず, 降雨 の形態 (降雨域の移動や減衰・成長) が無秩序に変化し ていないことがわかる．図一10は一降雨中に移動した 雨域中心の 15 分毎の位置を示したものである. 黒塗の
シンボルで表わしたのが1994.8.26, 白抜きは 1994.9.16の降雨である. 8.26 の降雨では, 一降雨中に 3 つの雨域が移動しているが, どの雨域の移動経路も直 線で進行方向はよ゙の雨域も平行に進んでいる.9.16の 降雨においても降雨期間中に風向が変化し, 雨域の進行 方向が変わっているが, 雨域の移動経路はほぼ直線であ 子.

\section{c）降雨域の移動速度と降雨域の発達}

図一11は雨域の移動速度と雨域面積の関係を表わし たものである。一つの雨域の移動速度と面積の変化する 範囲を四角で囲って表わしている. 雨域の移動速度は降 雨毎異なっているが, どの雨域とも20７0 km/h の範 囲で移動している。一降雨中には10以上の雨域が含ま れている場合もあるが, それらの雨域の移動速度は $30 \mathrm{~km} / \mathrm{h}$ 程度の範囲内で変化している. 図一12は雨域の 移動速度と面積をそれぞれの平均值で無次元化して, そ の変化の確立密度分布を示したものである. サンプリン グ数は約 250 で，20の雨域を対象としている.（a）に は移動速度，（b）には雨域面積について示してある. 移動速度は平均速度から $\pm 10 \%$ の変化の範囲に約 6 割 が含まれている. 数時間先までの移動速度は一起として 考えても予測精度上, 問題がないと言える. 雨域面積の 変化はほぼ正規分布している. 雨域面積が移動速度より も変化が大きいのは, 雨域の減衰, 発達があるためであ るが, 平均面積からは土10\%の変化の範囲に約 5 割が 含まれている.したがって, 雨域面積も移動速度と同様 に数時間は面積が変わらないとして予測を行っても問題 ないと言える.しかし, 雨域面積は予測地点での降雨継 続時間, さらに山地流域においては降雨強度 (増幅率) と密接に関係しているため，これらとの関連からも考察 


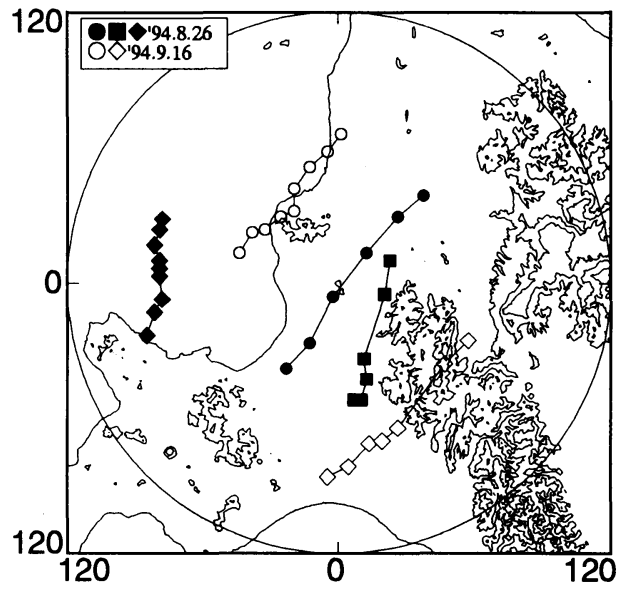

図一10 雨域中心の移動経路

(移動経路の一例, ○ $10 \mathrm{~mm} / \mathrm{hr}$ 以上の雨域の四心を示してい る.)

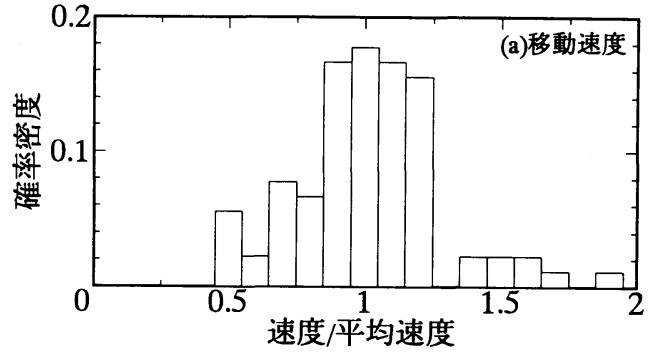

(a) 一雨での雨域の移動速度

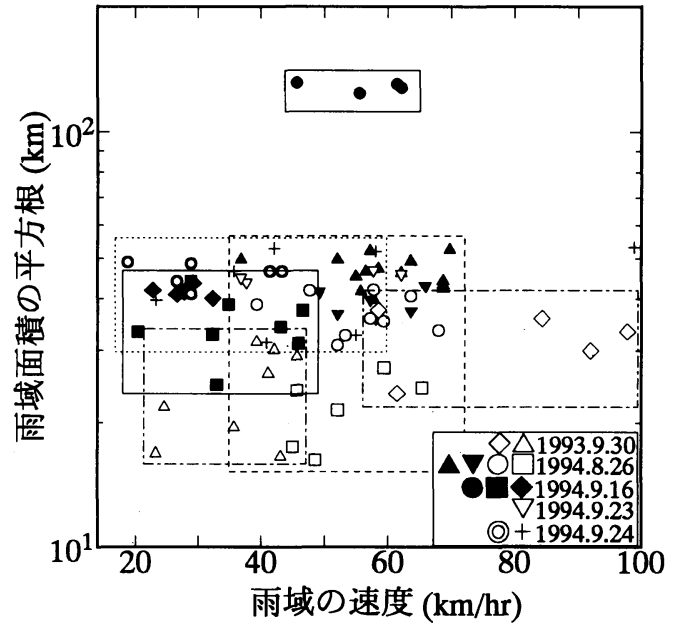

図一11 雨域の移動速度と雨域の大きさの関係 (移動速度は図一 10 から求めている. $10 \mathrm{~mm} / \mathrm{hr}$ 以上の面積)

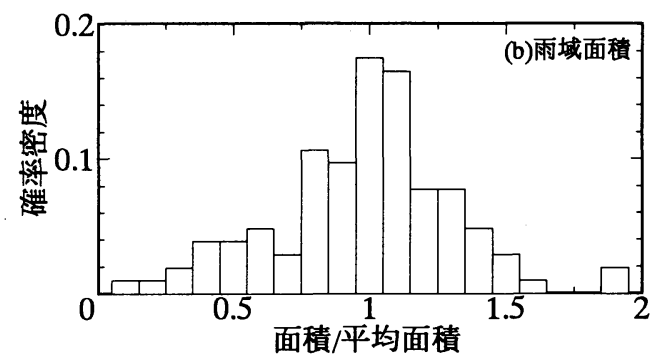

(b) 一雨での雨域の面積

図一12 無次元化された雨域の移動速度と面積の確率密度分布

(雨域の移動速度と面積をそれぞれの平均值で無次元化して表示している.)

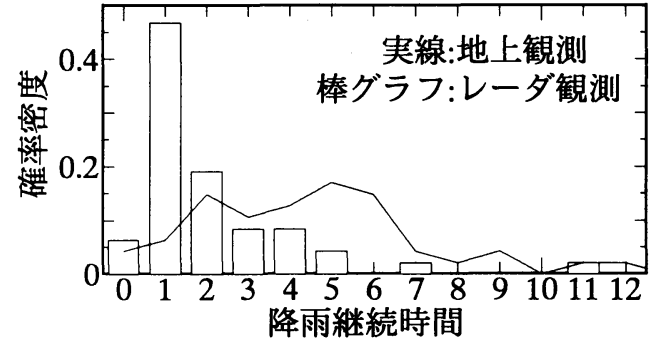

図一13 1つの雨域に対する降雨の継続時間

(1つの雨域は平均的に $1 \sim 2$ 時間の降雨を継続させる. )

を必要とする。

\section{d）降雨継続時間}

図一13には夕張岳で観測された 1 つの雨域の通過に 伴う降雨継続時間の確率密度分布が棒グラフで示されて いる. 図中実線で示したのは地上で観測された降雨の継 続時間を示している.レーダにより観測した場合と地上 で観測した場合では分布形状が異なっている。レーダ観 測では 1 つの雨域の通過に対して 1 2 時間の降雨が卓

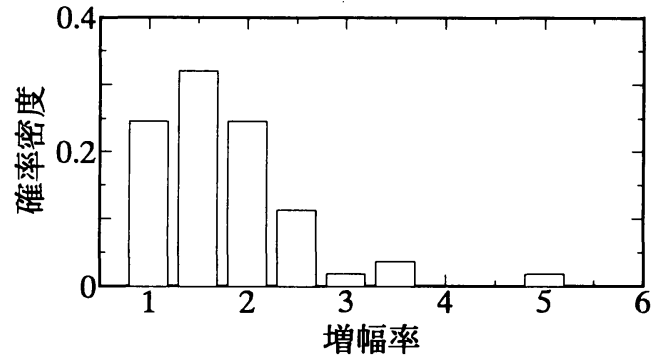

図一14 雨域の増幅率; 夕張岳の降雨強度/石狩平野の降雨強度 (山地部では平地部の 1.5-2.5 倍の降雨強度になる.)

越しているが地上観測では 5 6 時間の降雨が卓越して いる.これは地上においては雨域の移動を正確に捕らえ られていないためであり, 通常地上で一塊に観測される 雨は 3 つ程度の雨域が連続して通過することによってそ のように観測されるのである.1つの雨域の通過による 一地点での降雨継続時間はレーダ画像から得られるよう に平均で 2 時間程度と考えることができる. 


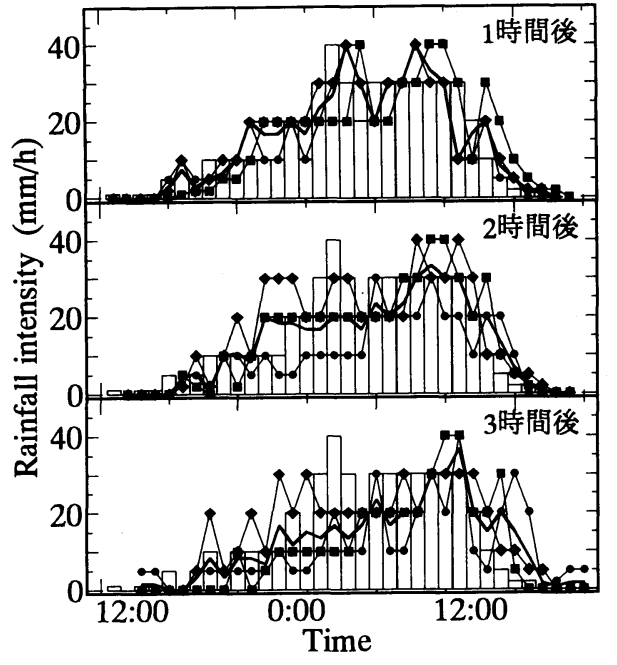

( $\mathrm{a}-1$ - 予測地点: 暑寒別岳

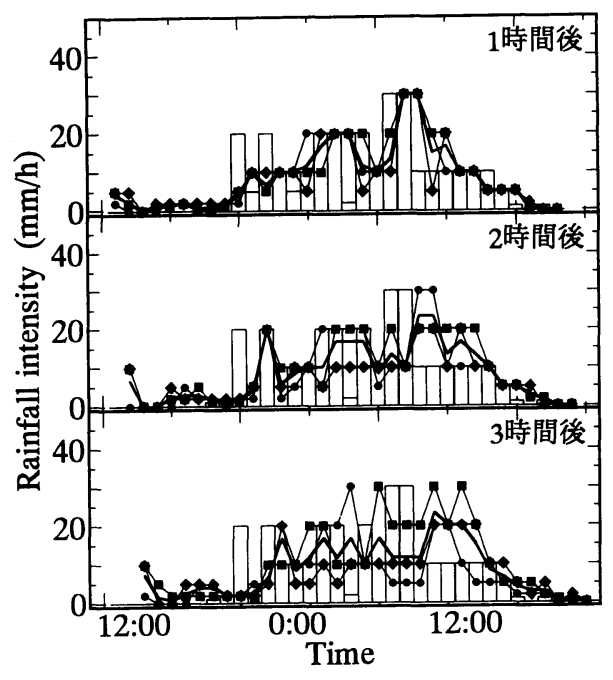

(a-2) 予測地点：夕張岳

図-15（a） 1994.9.19 11:00-19:00

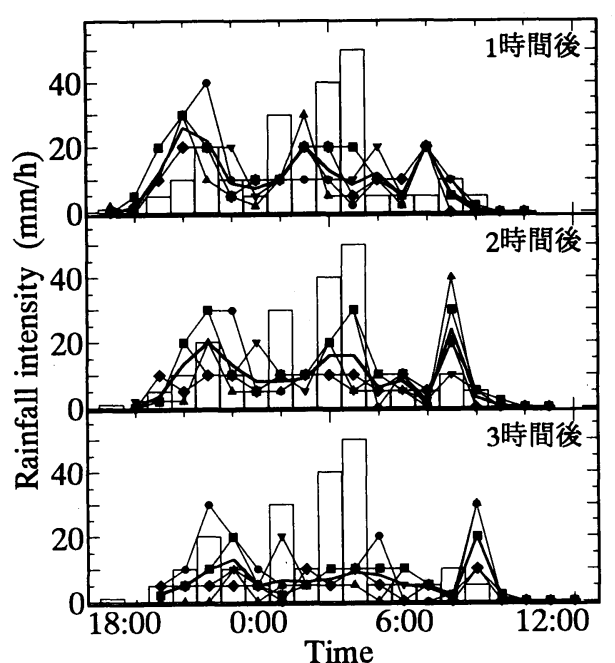

図一15（b）予測地点：夕張岳（1994.9.15 8:00-11:00）

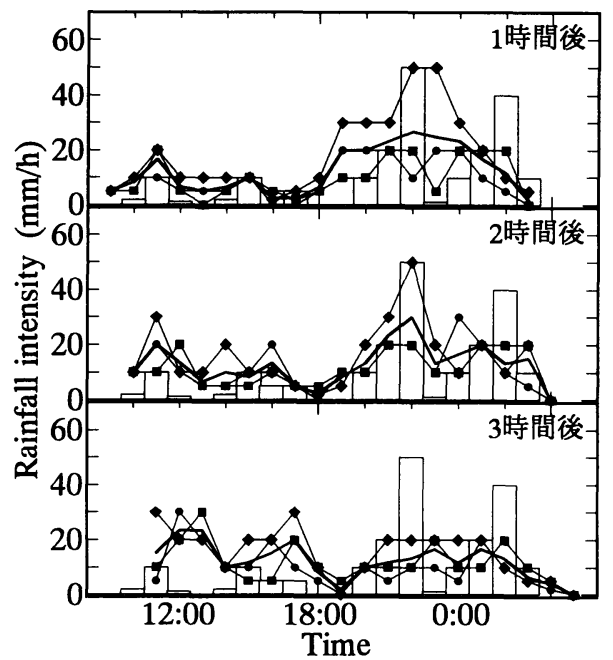

図一15 (c) 予測地点: 暑寒別岳 (1994.9.25 09:00-26 03:00)

図一15 短時間降雨予測結果

（動画化されたレーダ情報のみを用いる短時間予測を試みた。困中の印付線は各予測者の予測値，太線は予測の平均値）

\section{c）地形による降雨の増幅}

雨域が平地部から山地部に移流していく場合, 山地部 では降雨強度が増幅されるが，降雨予測を行うためには 地形によって増幅する程度を見積もることが重要とな る. 著者らの山地流域での降雨観測から降雨量は標高に 比例して増加する結果を得ているが，レーダによる観測 值は山地部の平均的な降雨強度を計測していることから 細かな増幅傾向を用いる必要はない。図一14には千歳 川流域と夕張岳での降雨強度の比 (増幅率) が示されて いる. 千歳川流域と夕張岳をともに通過する雨域を対象 としており, 雨域が両地域を通過した時の降雨継続時間
平均の降雨強度の比をとっている.この時，レーダ定数 は 3（1）節の方法で決定したものを使用している. 全 体の $75 \%$ の降雨（一雨域の通過による）で山地流域に おいて降雨強度が増幅しており，その増幅率は 1.5 2.5 倍である. 図一6で示した山地流域でレーダ定数の 値が変化する降雨（前線性の雨域の広い降雨）で増幅率 が大きくなる傾向が強い. この傾向はレーダ定数の変化 の傾向と類似しており, 降雨強度の増幅はレーダ定数の 同定 (雨滴径分布の観測) と併せて検討することが必要 である。 


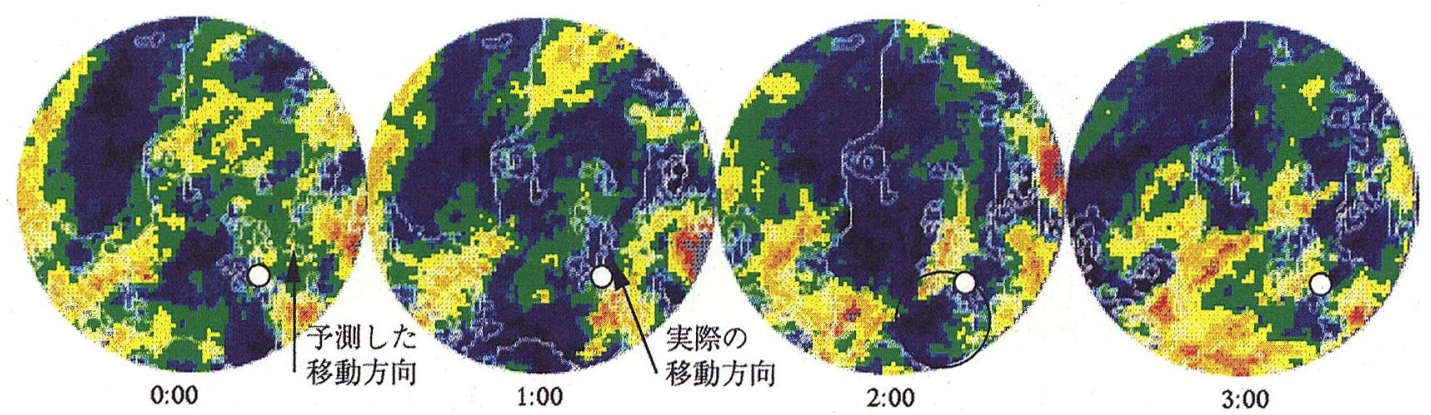

(0:00には北方向に移流すると予測したが，実際は北西方向に移流した．2:00には○で囲った部分の印象が強く，1時間後は夕 張岳では降雨強度は小さいと予測した.)

図一16 1994.9.15 (0:00-3:00) のレーダ画像（図 16，17 とも降雨強度と色の対応は図 8，9（b）と同一) (夕張岳での予測の精度が悪かった 1:00と 3:00 のレーダ画像を示している. 画像中に○で印したのが予測地点の夕張岳である. 亡゙ちらの場合も雨域が南から移流してくるために夕張岳までの距離が少なく，予測するための雨域の情報が少ないことが原因と なっている.)

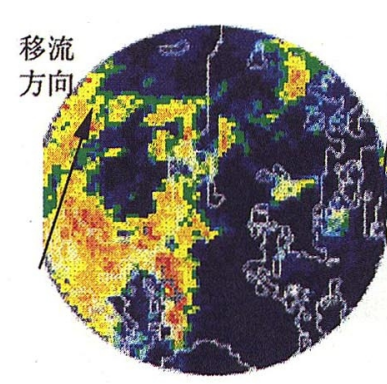

$20: 00$

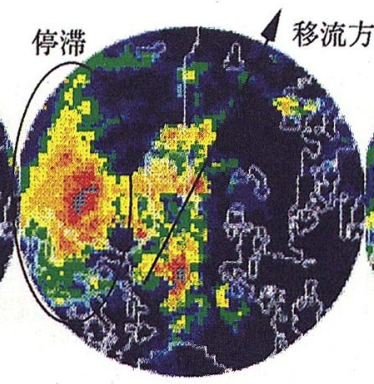

$21: 00$

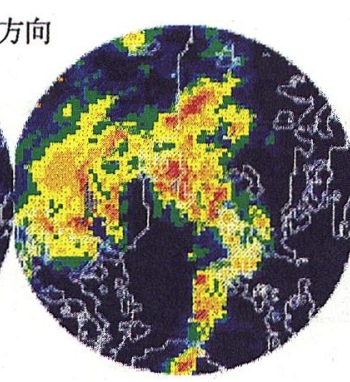

$22: 00$

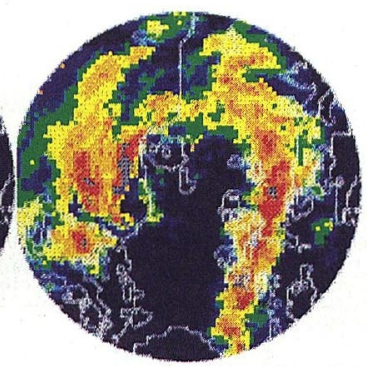

23:00

図一17 1994.9.25(20:00-23:00) のレーダ画像

(暑寒別岳での予測の精度が悪かった 22:00 付近のレーダ画像を示している. 画像中に○で囲んだ雨域は停滞しており，その右 に或る雨域は矢印方向に移動している．停滞する雨域の予測が困難である.)

\section{5. 降雨強度の短時間予測実験}

\section{（1）予測実験の方法}

降雨の短時間予測は以下に示す手順で行われた。i) 予測者を 2 ～ 3 人ずつのグループに分ける. 予測者は研 究室に配属されたばかりの学生で構成されている，ii） 予測者に画像に表示される色と降雨強度との対応を説明 する. iii）レーダサイト内の地形図を見せ, 予測地点を 知らせる。iv）予測を行う降雨の 3 時間前までの 5 分間 隔の観測值から作成した動画を見せる、V）見終わった 時点から 1 時間後, 2 時間後, 3 時間後の予測地点での 降雨強度を予測する，vi）次の予測時間分のレーダ動画 を見せて，v）に戻る，vii） v ）～vi）を降雨期間終了 時まで繰り返し行う. 予測地点は, 予測者が降雨の地形 による影響を正しく判断できるかぜうかを確かめる目的 で, 夕張岳と, 暑寒別岳の2ヶ所の山地部を選定した.

\section{(2) 予測結果}

図一15（a )〜 ( c ) にはレーダ雨量計によって観測さ
れた降雨強度 (実棒) と, 予測者らにより予測された降 雨強度 (実線) の時系列が示されている. 図 (b) と (c) には予測実験を行った10個の降雨の内, 予測が困難で あった2つの降雨についての実駼結果を示した. 図(a) には1994.9.19,（b）には1994.9.15，（c）には 1994.9.25 の降雨についての予測結果が示されている. 9.19 と 9.15 は雨域が広い範囲に及ぶ降雨であり， 9.19 は雨域が東から西，9.15 は南から北に移流する降雨で ある. 9.25 の降雨は雨域の境界がはっきりとしており, 滞留する雨域之移流する雨域が存在する特徵を有する. 図一15から予測者らは 1 時間後予測についてはレーダ 雨量㖕の観測值を的確に予測しており, 2 時間後, 3 時 間後においても雨域の成長・減衰を予測できていること がわかる.特に雨域が広域に拡がる降雨では図一15（a ) に示す結果と同様の精度で予測を行えることが確認でき た. 本実験では 10 個の降雨について降雨予測を行った が, 予測の回を重ねることによって, 予測者自身が, 雨 域の移動・成長パターンを学習して, 予測の精度が良く なっていくという学習の効果も確認することができた. 


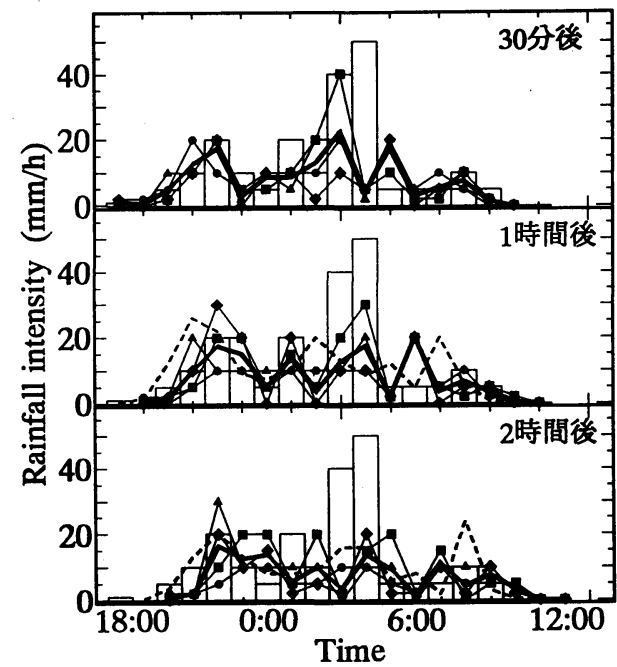

(a) 1994.9.15 18:00-11:00 (予測地点：夕張岳)

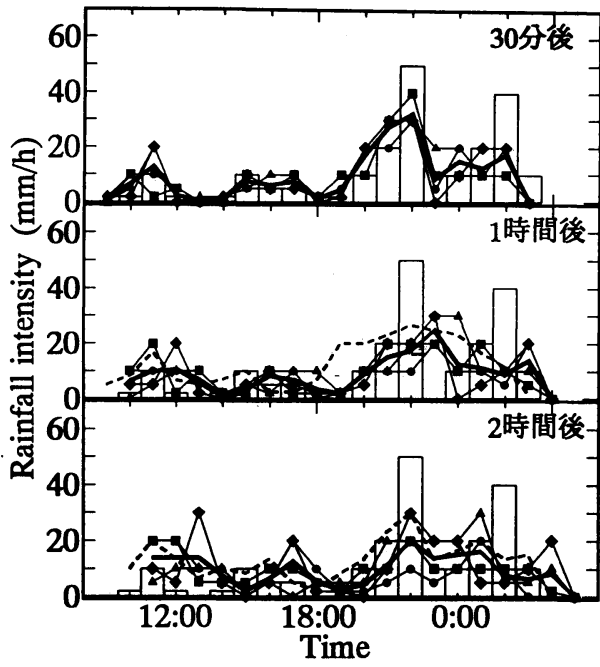

(b ) 1994.9.25 09:00-26 03:00 (予測地点：暑寒別岳)

図一18 短時間降雨予測結果

(動画と静止画を同時に用いた短時間予測結果. 印付線は各予測者の予測値，太線は予測の平均值，破線は図一15における平均值）

\section{（3）予測結果の分析}

予測実験の結果，次の 2 つ問題点を見いだすことが できた.

i ） 予測時間を 2 時間，3 時間とするにつれて，降雨 強度のピークを遅らせて予測する傾向にある。

ii ）降雨強度が急激に大きくなると，予測できていな い場合がある(図一15 ( a ) と（b )).

以下ではこれらの問題点を分析し，予測手法について 検討を行う.

i ）は予測時間に対してレーダの情報範囲が狭いこと による. 例えば雨域速度が $40 \mathrm{~km} / \mathrm{h}$ の場合， 3 時間後に は $120 \mathrm{~km}$ 進むことになるが，この距離はレーダの観測 半径に相当している. したがって, 予測のための移動速 度, 雨域面積の情報が極めて少ない状態で予測を行わな くてはならない。 ii ）に関して降雨強度の急激な変化を 予測できないのは雨域の侵入境界から予測地点までの距 離が短いこと（i）と同様）, 雨域の移動が特異であっ たことによる. 図一16 は夕張岳での予測の精度が悪かっ た 1994.9.15. 1:00と 3:00のレーダ画像とその1時間前 の画像を示している. 左端の画像中に○で印したのが予 測地点の夕張岳である. 図からわかるように雨域は南か ら北方向に向って移流している. 雨域の侵入境界から夕 張岳までの距離は約 $50 \mathrm{~km}$ と短く, 雨域の移動情報が 非常に乏しい. 夕張岳で $1: 00$ に $30 \mathrm{~mm} / \mathrm{h}$ の降雨強度を 予測できなかったのは，0:00の時点で矢印の方向に雨 域が移流すると予測したためである。また，3:00に予 測できなかったのは，2:00の時点で次に来る雨域を確 認できるにもかかわらず，実線で囲まれた雨の降ってい
ない部分の印象が強く，予測の判断を狂わせたためであ る。

図一17には図一15（c）で予測の精度が悪かった 1994.9.25（20:00-23:00）の画像を示している. 予測の 精度が悪かったのは暑寒別岳西側に滞留する雨域と北東 に移流する雨域が混在しており，それらの動きおよび増 幅率が複雑であったためである．20:00 に石狩湾に移流 してきた雨域は図中 21:00の画像内に実線で囲んだ地域 で滞留しているが, 千歳川流域に移流した雨域は増幅し つつ北東方向に移流している。このように滞留する雨域 が存在する場合にはどの状態で滞留している雨域がどう 動くか，いつ移流し始めるかは，メソスケールの場の状 態に依存しており,これを予測することは非常に難しい，

\section{（4）降雨情報の補足法}

数時間後の降雨予測を行う場合や予測地点が雨域の流 入境界から近い場合には雨域の移動情報が少なく, 予測 精度が低くなる.これに対しては周辺のレーダ情報を用 いることによって情報を与えることが望ましいが，ここ では，降雨情報が少ない場合に降雨情報を補足するため に過去の静止画像を用いた（見終わった動画像も同時に 表示する). さらに 30 分後の予測も行った. 過去の静止 画像も同時に使用することで予測者らは過去の情報から 移動経路，速度，方向を確認することができる．また， 30 分後の雨域の細かな動きを予測することによって予 測者に新たな情報を与えることができる．図一18（a） と（b) は動画之 15 分毎の静止画を同時に用いて 30 分, 1 時間, 2 時間後の降雨予測を行った結果である. 動画 


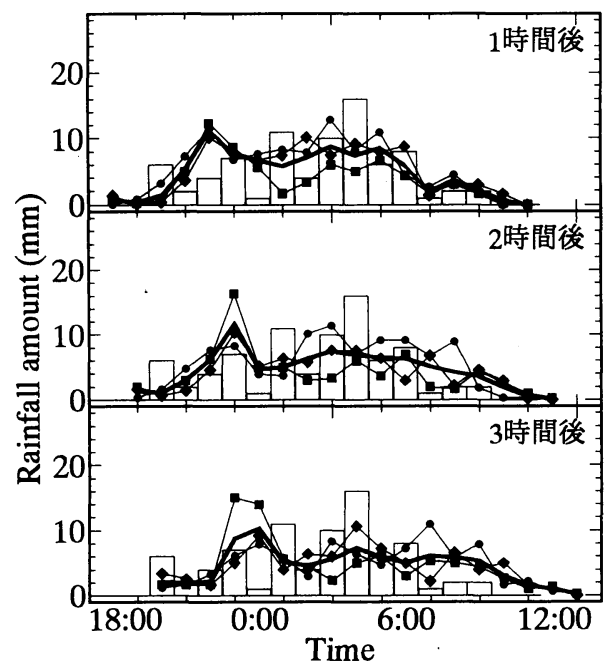

(a) 1994.9.15 18:00-16 11:00 (予測地点: 夕張岳)

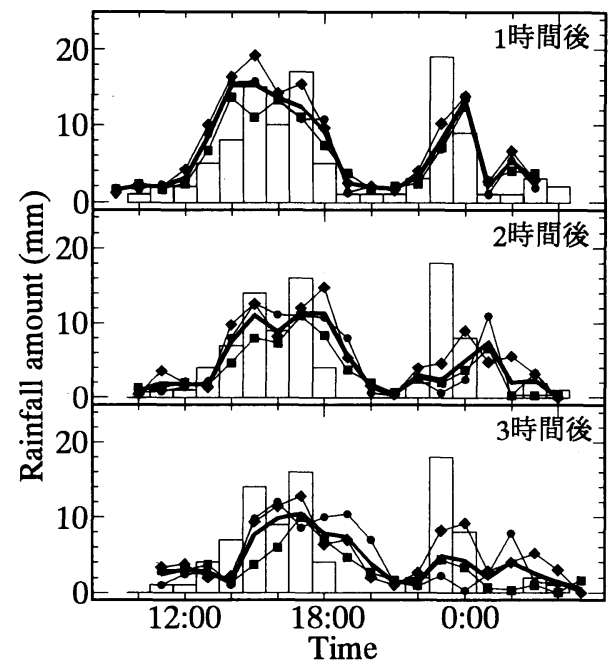

(b ) 1994.9.25 09:00-26 03:00 (予測地点: 夕張岳)

図一19 累積降雨量の短時間降雨予測結果

(動画と静止画を同時に用いた短時間予測結果. 印付線は各予測者の予測値，太線は予測の平均値）

のみを用いた場合に予測精度の悪かった 9.25 の暑寒別 岳 (図一15 (b)) と9.15の夕張岳 (図一15 (c )) の 予測結果が示されている．静止画像を同時に見せること のみでは完全に雨域の移動情報を補足することはできな いが，過去の静止画像を動画像と同時に見せることに よって予測精度を向上させることが可能となる.

\section{6. 累積降雨量の予測実験}

\section{（1）予測実験の方法}

降雨予測は数時間後の降雨強度の予測の他に総降雨量 も重要な予測項目としてある.総降雨量を予測する場合, 図一8 と図一 9 で示した累積降雨量の動画を用いる。累 積降雨量の動画を用いることでレーダサイト内において 降雨の集中する地域を実時間で認識していくことができ る.またこれにより予測地点における降雨の地域的な特 性を感覚的に捉えることができる．総降雨量の予測実験 は累積降雨量の動画を見せる以外は降雨強度の予測実験 と同様の方法で行った。ここでの 1 時間後予測は現時点 から 1 時間後までの 1 時間降雨量, 2 時間後予測は現時 点の 1 時間後から 2 時間後までの 1 時間降雨量の予測を 意味している.

\section{（2）予測結果と考察}

図一19には累積降雨量と降雨強度の瞬時値の動画を 用いて行った累積降雨量の予測結果が示されている. （a ）には1994.9.15-16，（b ）には1994.9.25-26のい ずれも予測地点を夕張岳としたときの 1 時間降雨量の予
測結果が示されている. 図より1時間後予測について予 測者らは精度良く降雨量を予測できている．2 時間後, 3 時間後予測では, 降雨量の変化の傾向は捕らえている ものの，精度良く予測ができているとは言えない，これ は降雨強度の予測の場合と同様にレーダ情報範囲が狭 く, 予測のための情報が十分でない為である.

この降雨量予測実験においても, 降雨強度の予測実験 の場合と同様に予測実験を重ねる毎に予測の精度が向上 するという学習の効果が確認できた.

\section{（）地上雨量計データを用いた累積降雨量の推定}

累積降雨量のレーダ動画を用いた降雨量予測で予測し きれない山地部では地上雨量計による降雨量予測を併用 することが有効である. 地上雨量計デー夕を用いた山地 での累積降雨量の推定法に関して著者らは以下の実験式 を提案している11). 累積降雨量のレーダ動画によって降 雨開始数時間後に降雨量が集中する地域を特定し, 集中 する地域が山地の場合そこでの降雨量は次式によって算 出することができる.

$$
P=P_{0}\left\{C \cdot\left(Z-h_{0}\right)+1\right\}
$$

ここに, $C$ は定数で $1 \times 10^{-3}(1 / \mathrm{m})$ の值をとる. $P_{0}(\mathrm{~mm})$ は標高 $h_{0}(\mathrm{~m})$ での降雨量で降雨の夕イプによって異な り, 次式によって表される ${ }^{11)}$.

$$
\begin{aligned}
& \text { 台風による降雨 } P_{0}=27 D^{0.45} \\
& \text { 台風以外の降雨 } P_{0}=3 D^{0.8}
\end{aligned}
$$

上式は標高 $Z(\mathrm{~m})$ における降雨継続時間 $D$ 時間の累 積降雨量を求める式で, 山地流域での著者らの観測より 
経験的に求められたものである.

また，式 $(4)$ ，（5）を時間 $D$ で微分すると

$$
\begin{aligned}
& d P_{0}=a D^{-b} d D \\
& d P_{0}=m D^{-n} d D
\end{aligned}
$$

となり, $a=12, b=0.55, m=2.4, n=0.2$ である.こ の式より時刻 $D$ から $D+d D$ の間の降雨量 $d P_{0}$ が推定で きる、興味深いことには, 上記の式形式 $(6),(7)$ は Talbot の式と共に河川計画, 下水道計画等に用いられ ているShermanの式と同形である.これを式（3）を 時間 $D$ で微分したものに代入して,

$$
d P=a D^{-b}\left\{c \cdot\left(Z-h_{0}\right)+1\right\} d D
$$

が得られる.この式より標高 $Z$ における時刻 $D$ から $D$ $+d D$ の $d D$ 間での降雨量を計画論的な意味において予 測することができる.

上記に示した個々の方法によっても降雨予測は可能で あるが,ささら精度の良い降雨予測を行うには降雨強度, 累積降雨量の動画およびそれらの静止画像, 観測から得 られる実験式を組み合わせて用いることが必要である.

\section{7. レーダ雨量計データを用いた流域平均降雨量 推定法としてのティーセン法の精度検証}

\section{（1）流域の選定と地上雨量計設置位置}

河川計画，洪水予報にとって河川流域に降った降雨に より流域の下流によ゙のような流量が生ずるかを推定する 事は最も重要な問題である. 流域内の降雨量分布を正確 に求めることは困難であるため, 流域内に設置された地 上雨量計の観測值から流域の平均降雨量を求める方法が 用いられている. 流域平均降雨量を算出する方法として （1）ティ一セン法（2）等雨量線法（3）算術平均法 がある.わが国ではティ一セン法が多く利用されており， その精度検証は地上での精密観測結果を用いて行われて いる.ここでは一雨毎にレーダ雨量計によって観測され た流域平均降雨量とティーセン法によって求められる流 域平均降雨量を地上雨量計台数, 時間スケール別で比較 することによりティーセン法の精度を検証した。

図一20には対象亡した流域 (千歳川流域) が太線で 示されている.この流域は実際の流域ではなくレーダ雨 量との比較を簡便にするためレーダ雨量計の観測メッ シュの範囲で選定したものであり，流域面積は約 720 $\mathrm{km}^{2}$ (レーダ雨量計の観測メッシュ数で 63 メッシュ) である. 流域内の平均標高は $90 \mathrm{~m}$ であり平坦な地形形 状である. 図中のはは地上雨量計の設置位置を表してお り，10 基の雨量計が設置されている.レーダ雨量計に より観測された降雨量データは, 地上雨量計のデータと 比較してレーダ定数を同定し直して算出したデータであ り，この値を用いて流域平均降雨量を求めている.

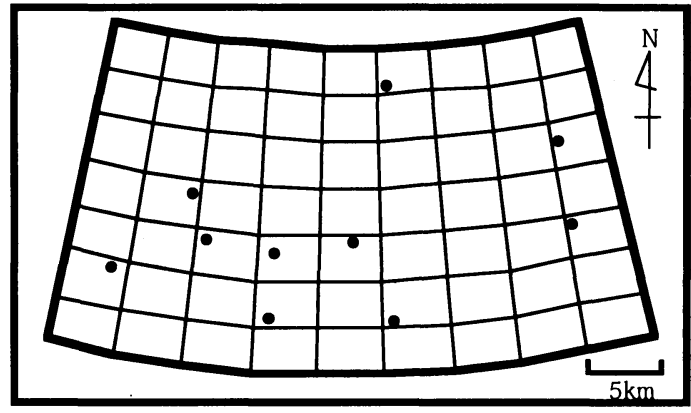

図一20 選定した流域と地上雨量計の設置位置 (太実線内がレーダ雨量計の観測メッシュ範囲で任意選定した流 域で, 流域面積は約 $720 \mathrm{~km}^{2}$ である. ○で示したのが地上雨量 計の設置位置を表しており 10 基設置されている. )

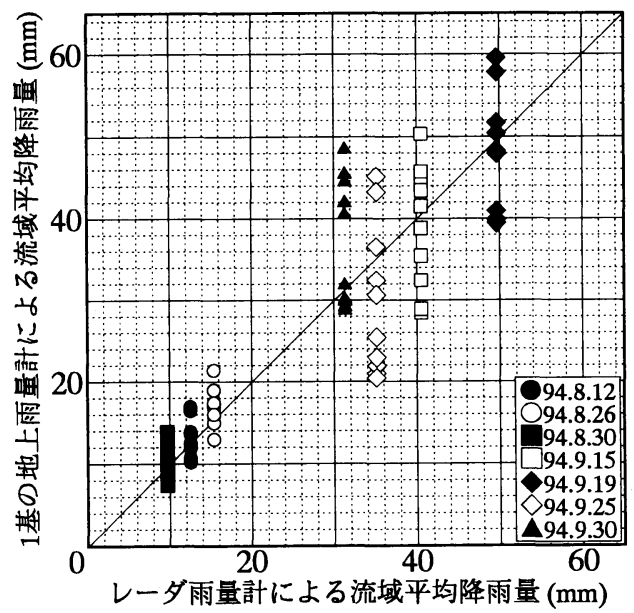

図一21 1 基の地上雨量計観測值から推定した流域平均降雨量 とレーダ雨量計により求められた流域平均降雨量の比 較 (一雨)

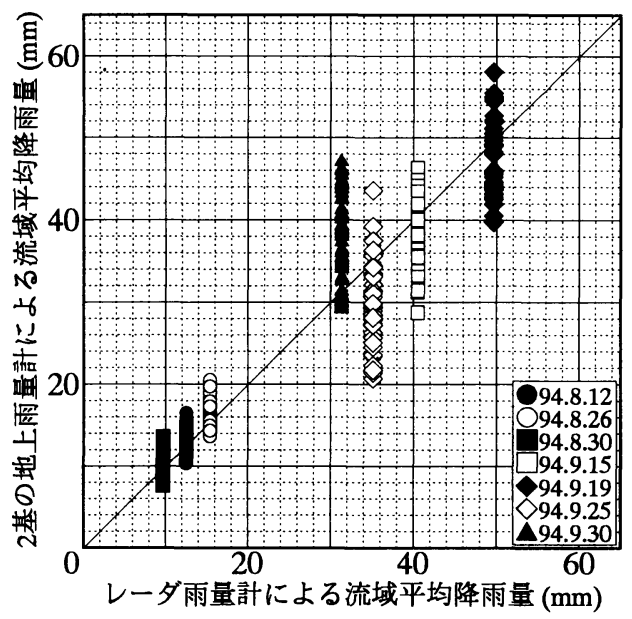

図一22 2 基の地上雨量計観測值から推定した流域平均降雨量 とレーダ雨量計により求められた流域平均降雨量との 比較 (一雨) 


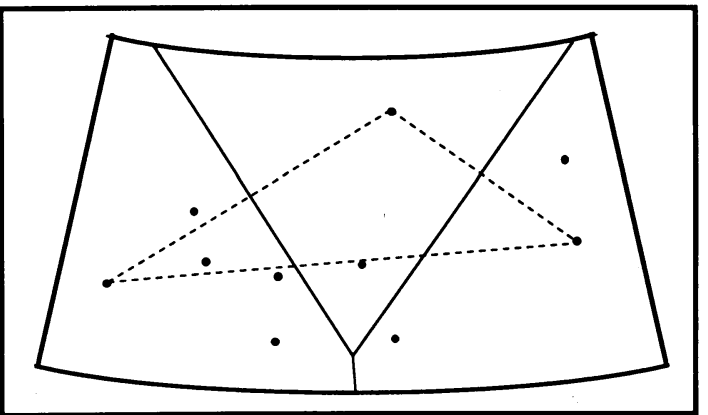

(a) 地上雨量計 3 基

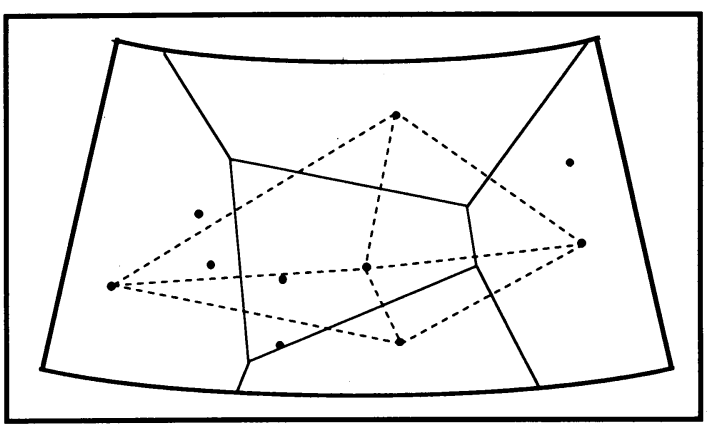

(b) 地上雨量計 5 基

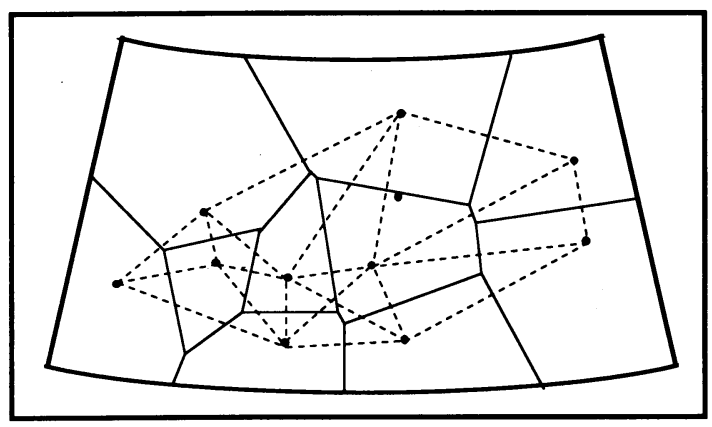

(c) 地上雨量計 10 基

図一23 地上雨量計を 3 基， 5 基，10 基としたときのティーセ ン法による流域分割闵

（実線はティーセン法により分割された区域を示している.）

\section{（2）ティーセン法による流域の分割数と精度}

ティーセン法による流域の分割数と精度の関係を確か めるために, 利用する地上雨量計の台数を $1,2,3,5$, 10 基で比較した.

図一21には観測された 7 降雨について流域内の平均 降雨量を任意の 1 基の地上雨量計データで代表したとき の流域平均降雨量とレーダ雨量計により求められた流域 平均降雨量が比較されている. 図からどの降雨について も流域内では各雨量計の值にばらつきがあり，流域平均 降雨量を任意の 1 基の地上雨量計データで代表すること は困難であることがわかる.

図一22には流域内の流域平均降雨量を任意の 2 基の 地上雨量計データで代表させてレーダ雨量計により求め

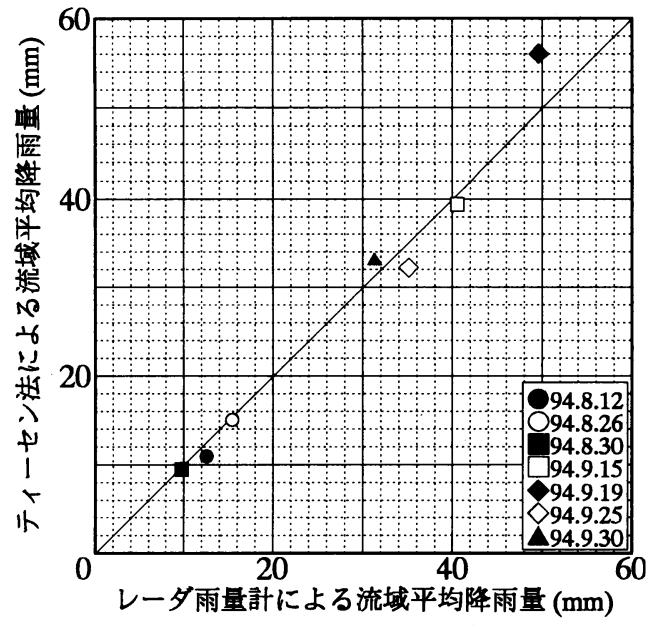

(a) 流域分割数 3

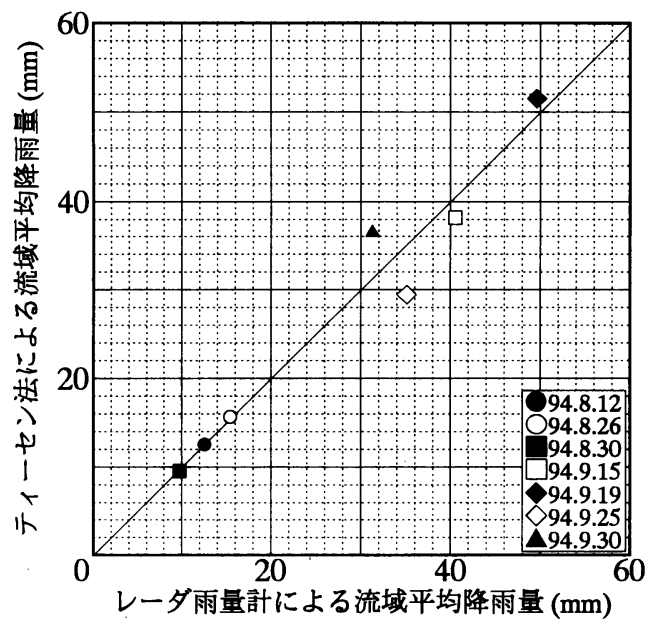

(b) 流域分割数 5

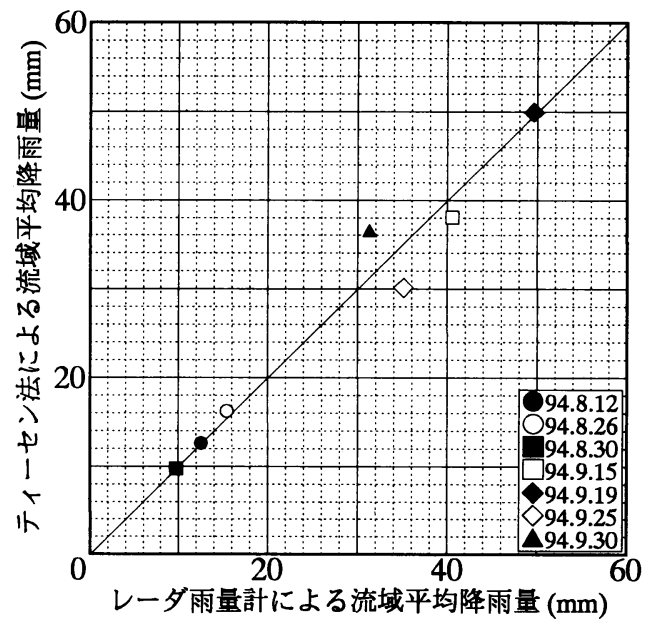

(c) 流域分割数 10

図一-24 地上雨量計を 3 基，5 基，10 基としたときのティーセ ン法により推定した流域平均降雨量よレーダ雨量計に より求められた流域平均降雨量の比較 (一雨降雨量の 比較) 


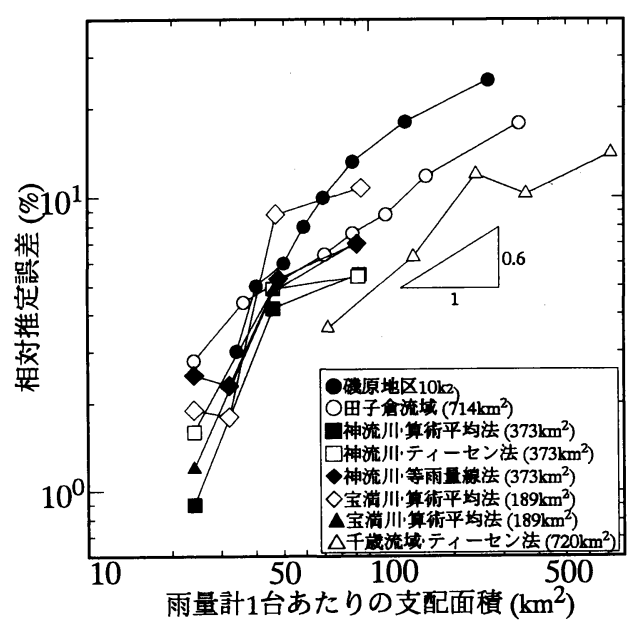

図一25 雨量計1台あたりの支配面積と相対推定誤差の関係 (一 雨降雨量での比較）橋本らによりまとめられた図に著 者らのデー夕を追加したものである．

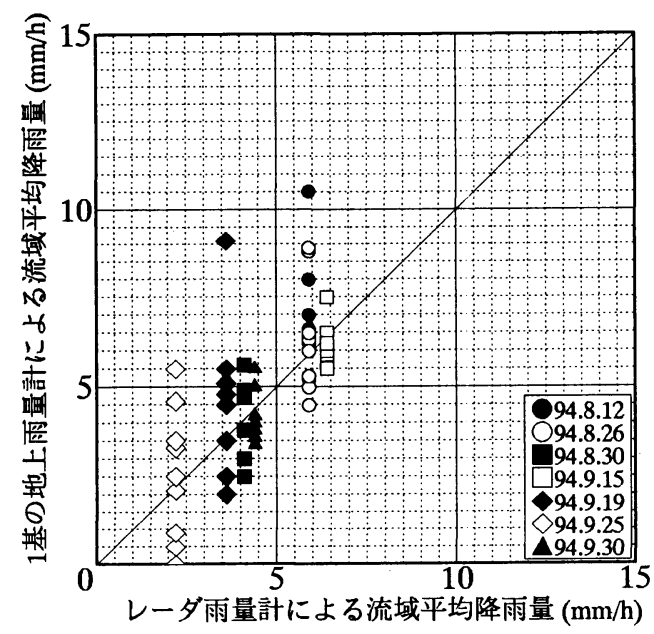

図一26 1 基の地上雨量計観測值から推定した流域平均降雨量 とレーダ雨量計により求められた流域平均降雨量との 比較 (一雨中最大降雨時 1 時間雨量の比較)

られた流域平均降雨量と比較されている．1 基の地上雨 量計の観測值が代表する流域内の区域の割り当ては，任 意に地上雨量計による観測点を 2 地点選び 2 点を結ぶ辺 の垂直 2 等分線により分割された区域とした．地上雨量 計デー夕により推定された流域平均降雨量は, 選定する 2地点の地上雨量計データがレーダ雨量計で求めた流域 平均降雨量の值に近い場合は両者は良い一致を示すが, 降雨が流域内に偏って降る場合は図のように最大で 60\% の誤差がでてくる.

図一23には使用する地上雨量計の台数を（a） 3 基, （b ） 5 基，（c） 10 基としたときのティーセン法による 流域分割図が示されている. 図中の点線はティーセン法

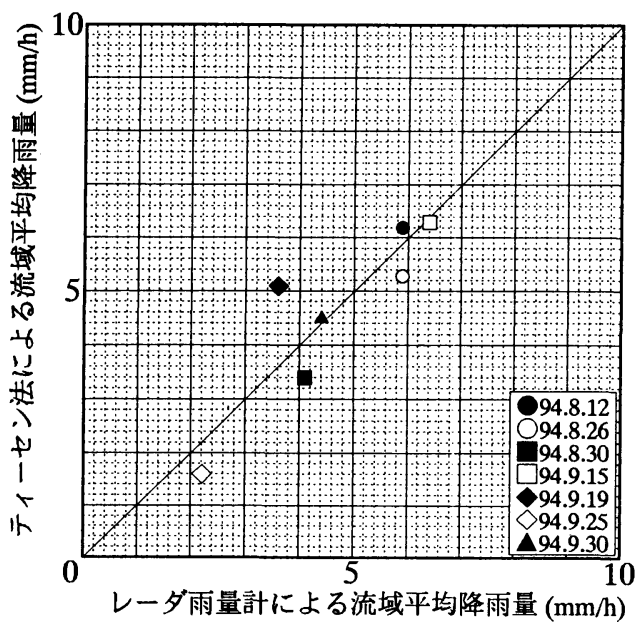

(a) 流域分割数 3

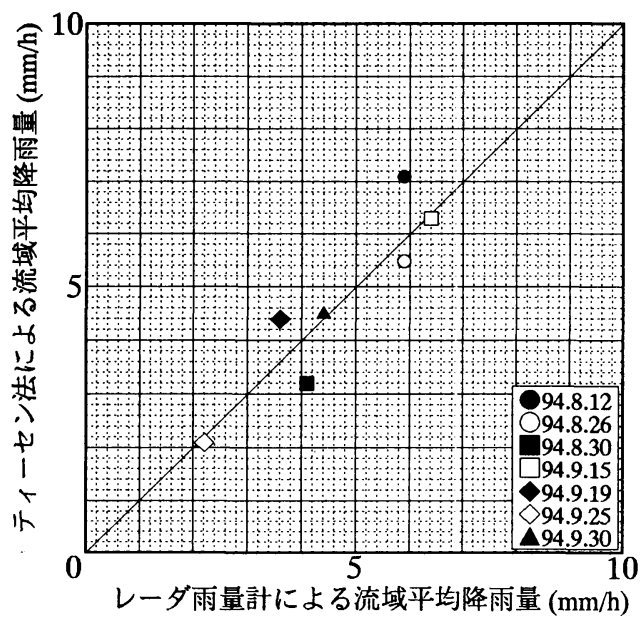

(b) 流域分割数 5

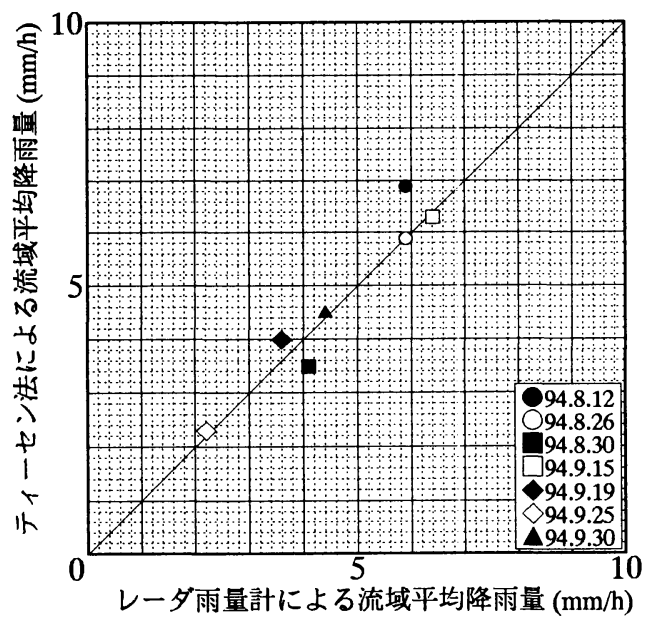

(c) 流域分割数 10

図一27 地上雨量計を 3 基， 5 基，10 基としたときのティーセ ン法により推定した流域平均降雨量とレーダ雨量計に より求められた流域平均降雨量の比較 (一雨中最大降 雨時の 1 時間降雨量の比較) 
で使用する地上雨量計を結ぶ線で，実線はティーセン法 により分割された区域の境界を示している．図一24に は図一23に示した各雨量計台数でティーセン法により 求められた流域平均降雨量とレーダ雨量計により求めら れた流域平均降雨量を比較した図が示されている. 図か ら分割数の多少にかかわらずティーセン法により求めた 流域平均降雨量とレーダ雨量計により観測された流域平 均降雨量はよく一致している事がわかる.ティ一セン法 による流域分割数が多い（流域内に雨量計設置台数が多 い）程, 正確に流域平均降雨量が推定できると予想され たが, 選定した流域（流域面積約 $720 \mathrm{~km}^{2}$ ) に対して地 上雨量計の数が 3 基だけでも十分な精度で流域平均降雨 量を推定する事ができた．図一24（b ），（c）の 1994. 9.25 (図中〉) と 1994.9.30 (図中心) に観測された降 雨についてはレーダ雨量計により観測された流域平均降 雨量とは $5 \mathrm{~mm}$ 程度の開きがある。これは地上雨量計の データのばらつきに偏りがあったためである. 同様のこ とは図一23 の流域分割が 3 個の時にも言えるが, 選定 した 3 基の地上雨量計のデータが偶然均等にばらついて いるためレーダ雨量計により得られた流域平均降雨量之 良く一致している．いずれにしてもこの程度の誤差であ れば実用上問題ない範囲であり，ティーセン法による流 域平均降雨量の推定は精度良く行えることが分かる.

図一 25 は橋本らによりま亡められた雨量計 1 台あた りの支配面積と相対推定誤差の関係の図に本研究で扱つ

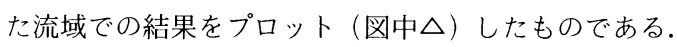
相対推定誤差を求める誤差公式は小林 ${ }^{12)}$ により提案され ており，次式で表される.

$$
\begin{gathered}
\sigma^{2}=\int_{A}(p-P)^{2} d A / A \\
\frac{\Delta P}{P}=0.819 \frac{\sigma}{P} n^{-0.636}
\end{gathered}
$$

ここに $\sigma$ は降雨の面積的な標準偏差, $A$ は流域面積で $A$ $=\int_{A} d A, P$ は面積雨量で $P=\int_{A} P d A / A, p$ は地点雨量, $n$ は雨量計台数である. 図から本研究で扱った流域での 結果は, 他の流域之同様に雨量計 1 台あたりの支配面積 が小さくなる程相対推定誤差が小さくなっているという 傾向にあり，他の流域と比へ雨量計 1 台あたりの支配面 積が同じでも相対推定誤差が小さくなっておりティーセ ン法の精度が良好であることがわかる.

\section{（３）ティーセン法の精度と時間の関係}

図一26には図一 21 亡同様の方法でティーセン法と レーダ雨量計により求められた流域平均降雨量が1時間 雨量で比較されている. 図中のレーダ雨量計により求め た流域平均降雨量は一雨期間中最も降雨量が多かった時 間雨量で求めている. 図より一雨で比較したときよりも ティーセン法により推定された流域平均降雨量のばらつ

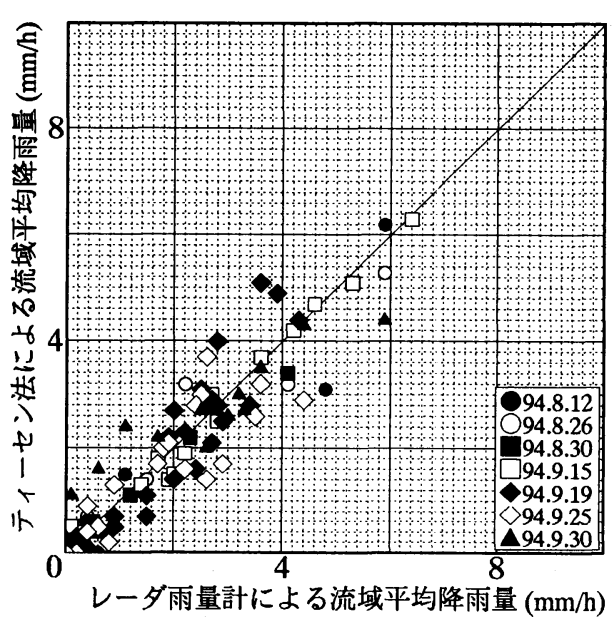

(a) 流域分割数 3

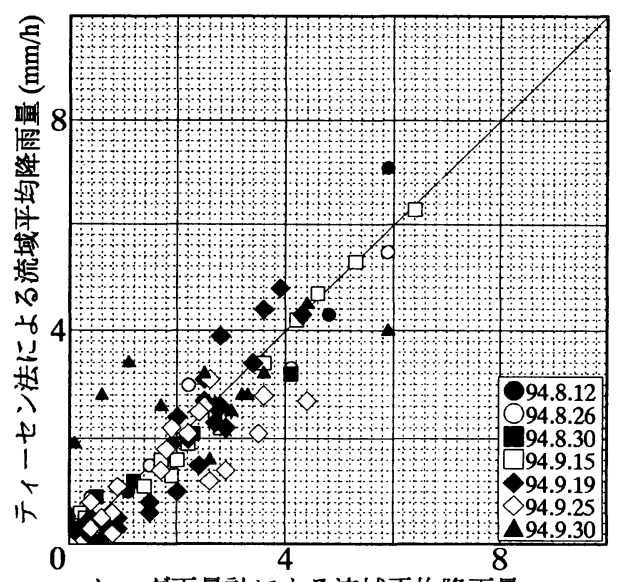

レーダ雨量計による流域平均降雨量 $(\mathrm{mm} / \mathrm{h})$

(b) 流域分割数 5

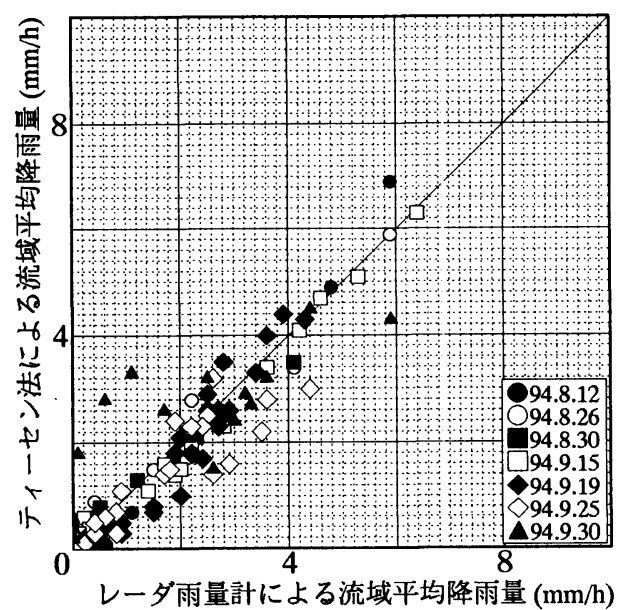

(c) 流域分割数 10

図一28 地上雨量計を 3 基， 5 基，10 基としたときのティーセ ン法により推定した流域平均降雨量とレーダ雨量計に より求められた流域平均降雨量の比較 (一雨期間中の 1 時間降雨量での比較) 
きが大きいのは 1 時間雨量の場合雨域の移動に伴い流域 内の降雨量分布に偏っているためである.

図-27には図-26と同じ時間（一雨期間中最大時間 降雨量時の1時間）で地上雨量計を（a ） 3 基，（b ） 5 基, （c）10 基とした場合のティーセン法により推定した流 域平均降雨量がレーダ雨量計により求められた流域平均 降雨量と比較されている。一雨降雨量で比較した場合と 比べると精度は落ちるが, 流域分割数を増やす（地上雨 量計の台数を増やす) 程, 精度が良くなっている.これ は流域内の降雨量の偏りを地上雨量計で捕らえているた めである. 10 基の雨量計を用いてティーセン法より推 定した流域平均降雨量はレーダ雨量計より求めた流域平 均降雨量と比較して最大で約 $17 \%$ の誤差となっている. 一雨降雨量で比較した場合は流域内にほぼ均等に降雨が 観測されていたため，流域の分割数に依存せず両者は良 い一致を示したが，1時間雨量のように流域内で降雨量 分布に偏りがある場合は流域の分割数を多くするほど精 度は向上する。

図一28には図一25で示した降雨について一雨期間を 通して1時間雨量でティーセン法とレーダ雨量計により 求められる流域平均降雨量が比較されている. ティ一セ ン法による流域の分割数が多いほど精度は良くなり, 10 基の地上雨量計を用いた場合で最大約 $20 \%$ の誤差と なっている. 1994.9.30（図中二）の降雨について一部 ティーセン法による流域平均降雨量がレーダ雨量計で求 めたものと合わないのは, レーダ雨量計が地上雨量を捕 らえきれていない事が原因である。

本研究で扱った流域において流域内の地上雨量計台数 を $1,2 ， 3 ， 5 ， 10$ と変えてティ一セン法により流域平 均降雨量を推定し, レーダ雨量計により求められる流域 平均降雨量と比較した. 雨量計1台あたりの支配面積が 小さく（流域分割数が多く）なるに従って相対推定誤差 は面積の 0.6 乗で小さくなっており, 橋本らにより示さ れた結果亡同様の結果を得た. 橋本らにより雨量計 1 台 あたりの支配面積と相対推定誤差の関係がまとめられた 当時, レーダ雨量計は普及しておらず仮想真値を地上で の精密観測から求めなければならなかっが, そのような 環境のもとでの橋本らの研究成果は貴重なものであると 言えよう.

\section{8. ま と め}

本研究ではレーダ雨量計の観測特性を把握し, レーダ 雨量計の観測精度を向上させた. また,この降雨データ 動画化し, 降雨予測を行った. 更にレーダ雨量計の面的 に得られるデータを利用してティーセン法の精度を検証 した. 以下に本研究の成果を要約する.

\section{（1）レーダ雨量計の観測特性}

a) 一降雨中, 逐次レーダ定数を変化させなくても一定 のレーダ定数を用いることによって実用的な精度を 確保することができる.

b) レーダ雨量計は降雨毎にレーダ定数を同定し直すこ とによって定量的に降雨強度を推定することができ る.

c) レーダ定数は一雨毎用いる值を変える必要がある が, レーダ定数はランダムな值をとるのではなく, 降雨のタイプによってその分布範囲は決まってく る.

d）レーダ定数の值は平地と山地で異なる場合がある. 特に, 数 $100 \mathrm{~km}$ のスケールで雨域が広がっている 降雨では, 平地と山地でレ一ダ定数の值を変える必 要がある。

\section{（2）動画から得られた降雨の特性}

a) 一雨中には数個の雨域が存在している. 降雨量が多 い場合には, 先ず, 数個の雨域 (数 $10 \mathrm{~km}$ のスケー ル）群が移流していき, その後 $100 \mathrm{~km}$ スケールの 雨域によって強い雨量がもたらされる場合が多い.

b）地形の影響を受ける雨域の成長及び移動パターンは 大きく3つのパターンに分類される.

c) 観測した全ての降雨において, 降雨のタイプによら ず降雨量の多い地域が集中する特性がある.

d）レーダ観測範囲内では個々の雨域の移動方向は一定 で，かつ移動経路はほぼ直線である.

e) 予測を行う数時間後までは雨域の移動速度及び面積 の変化はほぼ一定であると考えることができる.

\section{（3）降雨の短時間予測}

a) 動画像のみを用いた降雨の予測において以下の結果 を得た。

i ) 1 時間後予測については, 予測者は降雨強度を的確 に予測していることが分かった. 2 時間後，3時間 後予測については降雨強度についての予測は 1 時間 後予測より精度が下がるが, 雨域の成長・減衰は的 確に判断することができる.

ii ）降雨域の進行方向, 速度によりレーダの情報範囲が 狭い場合には予測が困難になる。

iii）リードタイムの範囲内で雨域の移動経路が突然変化 したり, 降雨強度が急激に変化する場合には予測が 困難である.

b）レーダ情報を用いて降雨を予測する場合，降雨強度 及び累積降雨量の動画像, 降雨強度の静止画像を同 時に用いることによって精度の高い降雨予測を行う ことができる.

c) レーダ雨量を累積し, 動画にすることによって降雨 
が集中する地域を特定できることから，特定された 地域の総降雨量を予測することが可能である.

\section{（4）ティーセン法の精度}

a) 本研究で扱った流域（流域面積約 $720 \mathrm{~km}^{2}$, 平均標 高約 $90 \mathrm{~m}$ ）では, 流域内に設置された 1 基の地上 雨量計のデータだけで流域の平均降雨量を代表させ ると相対推定誤差は $14 \%$ となる．任意の2基の地上 雨量計のデータで流域平均降雨量を推定すると相対 推定誤差は $10 \%$ である.

b）雨量計1台あたりの支配面積が小さくなるに従って 相対推定誤差は面積の 0.6 乗で小さくなり, 雨量計 1 台あたりの支配面積が最小の $72 \mathrm{~km}^{2}$ で相対推定 誤差は $3 \%$ となる.

c) 時間スケールを 1 時間としたときの流域平均降雨量 の比較についても時間スケールが一雨の場合と同様 に，雨量計 1 台あたりの支配面積が小さくなるほど 相対推定䛊差は小さくなり, 雨量計 1 台あたりの支 配面積が最も小さい $72 \mathrm{~km}^{2}$ の時, 相対推定誤差は $6 \%$ となっている.

\section{参考文献}

1）立平良三, 牧野義久：デジタル化されたエコーパターン の予報への利用，研究時報 26, pp. 188-199, 1974.

2) Asai, T. etc. : Some Results on an objective analysis for tracking radar echoes of convective clouds, J. Met. Soc. Japan 55, pp.553-557, 1977.

3）大倉博ら：レーダ雨量計を用いた短時間降雨予測，第 27 回水理講演会論文集, pp. 349-354, 1983.

4）吉野文雄, 水野雅光, 朝夫：雨域追跡法による短時間降 雨予測の精度, 第 31 回水理講演会論文集, pp. 209-214, 1987.

5）建設省土木研究所河川部水文研究室：レーダ雨量計によ る短時間降雨予測に関する調查報告書, 土木研究所資料 第 2406 号, 1986.

6）椎葉充晴ら：移流モデルによる短時間降雨予測手法の検 討, 第 28 回水理講演会論文集, pp. 423-428, 1984.
7）中津川誠, 竹本成行, 山田正：流域ス一ケルの降雨特性 の研究 (その 4 )-降雨予測について-, 北海道開発局開発 土木研究所月報第 449 号, pp. 19-29, 1990.

8）森山聡之, 平野宗夫, 河原田寿紀, 原浩：移流拡散モデ ルによる短時間降雨予測, 第 29 回水理講演会論文集, pp. 203-208, 1985.

9）橋本健, 佐藤一郎 : 面積雨量の精度と雨量観測所数, 土 木技術資料, Vol. 16, No. 12, pp. 35-41， 1974.

10）山田正, 日比野忠史, 鈴木敦, 壴島弥成, 中津川誠：新 しいタイプのレーザー雨滴計測の開発とこれを用いた降 雨の雨滴粒径分布の観測, 土木学会論文集, No. 539, II -35 , pp. 15-30.

11）山田正, 日比野忠史, 荒木隆, 中津川誠：山地流域での 降雨特性に関する統計的解析, 土木学会論文集, No. 527, II -33, pp. 1-13， 1995.

12）小林勉：平均雨量の誤差と雨量計の数および計算方法と の関係, 電力気像連絡会彙報, Vol. 11, No. 1, 昭和 53 年.

13）中津川誠, 竹本成行, 山田正：流域スーケルの降雨特性 の研究 (その 3 )-山地流域における気流と降雨のシミュ レーション-, 北海道開発局開発土木研究所月報第 447 号, pp. 20-35, 1990.

14）山田正：降雨予測と洪水予測，水文・水資源学会研修会 講義集, pp. 109-129, 1993.

15）山田正 : 地形性降雨とその解析, 土木学会・水工学に関 する夏期研修会講義集, A-8, pp. 1-21， 1992.

16）山田正, 日比野忠史, 森永博史, 中津川誠：動画によるレ一 夕゙画像の解析, 水文・水資源学会 1994 年研究発表会要旨 集, pp. 214-215, 1994.

17）吉野文雄：レーダ水文学の発展と課題ーレーダによる降水 強度の定量観測を中心として-：土木学会論文集, No. II -27, pp. 15-30, 1994.

18）中津川誠, 宮下考治：降雨生成過程を考慮した実用的レー 夕゙降雨予測, 土木学会第 50 回年次学術講演会講演概要集 第 2 部 (A), pp. 30-31, 1995.

19）山田正, 日比野忠史, 藤沢充哲, 中津川誠：レーダ動画 を用いた短時間降雨予測の可能性に関する研究，土木学 会第 50 回年次学術講演会講演概要集第 2 部 (A), pp. 32-33, 1995.

(1996.1.11 受付)

\title{
STUDIES ON SHORT-TERM RAINFALL PREDICTION USING ANIMATION OF RADAR IMAGES AND ESTIMATION OF AVERAGE-RAINFALL-DEPTH OVER A WATERSHED
}

\author{
Tadashi YAMADA, Tadashi HIBINO, Makoto NAKATSUGAWA, \\ Mitsuaki FUJISAWA and Hiroshi MORINAGA
}

\begin{abstract}
By using radar raingauge images and its animation, a short-term prediction method of rainfall intensity is proposed, and the precision and applicability of Thiessen method to estimate the average-rainfall-depth over a watershed is investigated. The short-term rainfall prediction through judging the animation by eyes shows good agreement with the rainfall intensity observed by raingauges installed on the ground.Further, we estimated the average-rainfall-depth over a watershed from the radar, and compared its results with the average-depth calculated by the conventional method using Thiessen method. Finally, we clarified the effects of deviding numbers of a watershed in Thiessen method on the estimation of average-rainfall-depth.
\end{abstract}

